\title{
Müşteri Deneyimi Oluşturma ve Deneyimsel Pazarlama: Iyaşpark Alışveriş Merkezi (AVM) Müşterileri ile Bir Araştırma ${ }^{1}$
}

\author{
Fikriye YEŞILOT ${ }^{*}(\mathbb{D})$, Nil Esra DAL ${ }^{2}$ \\ ${ }^{1}$ Burdur Mehmet Akif Ersoy University, Social Sciences Institute, Burdur, Turkey \\ ${ }^{2}$ Asst. Prof. Dr., Burdur Mehmet Akif Ersoy University, Bucak Faculty of Business, Department of Business \\ Administration, Burdur, Turkey
}

Geliș Tarihi/Received: 10.08.2019

Kabul Tarihi/Accepted: 09.09.2019
Doi: doi.org/10.31200/makuubd.604936

Araştırma Makalesi/Research Article

\section{ÖZET}

Günümüzde yaşanan teknolojik ve ekonomik gelişmeler pazarlama dünyasında büyük değişiklikleri beraberinde getirmiştir. Günümüz müşterisinin değişen istek ve ihtiyaçlarındaki farklılaşma giderek artmaktadır. Ürün ve hizmetten beklenen fonksiyonel fayda yerini duygusal ve sembolik değerlere bırakmıştır. Yoğun rekabet ortamında müşteriye sadece hizmet sunmak yetersiz kalmıştır. Müşteri fayda sağlayan ürün ve hizmet satın almaktan ziyade, duygu odaklı müşteri deneyimi sağlamaya yönelmektedir. Hizmetlerin müşteriler için bireyselleştirilmesiyle birlikte deneyim ekonomisi kavramı gelişmiştir. Deneyim ekonomisi sayesinde deneyimsel pazarlama ortaya çıkmıştır. Günümüzün en popüler mekânları olan AVM'ler tüketiciye deneyim sunan, tüketicinin iyi vakit geçirmesini sağlayan, sosyalleşme ve eğlence merkezleri halini almıştır. Böylece AVM'ler yoğun rekabet ortamında deneyimsel pazarlamaya ve müşteri deneyimlerine önem vermektedir.

Araştırmanın konusu, müşteri deneyimi üzerinde etkili olan stratejik deneyimsel pazarlama boyutlarını ortaya koyarak müşterilerin alışveriş merkezi deneyimini tavsiye etme ya da tavsiye etmeme durumunu tespit etmektir. Araştırmanın amacı, AVM müşterilerinin alışveriş alışkanlıklarını tespit edip, alışveriş deneyimlerini deneyimsel pazarlama açısından ele alarak stratejik deneyimsel pazarlama boyutları bağlamında incelemektir. Araştırmada Iyaşpark alışveriş merkezinden alışveriş yapan 483 kişiye çevrimiçi anket uygulanmıştır. Araştırmada, normal dağılım testi, güvenilirlik analizi, frekans analizi, Kruskal Wallis testi ve Mann Whitney

\footnotetext{
${ }^{1}$ Bu makale Burdur Mehmet Akif Ersoy Üniversitesi, Sosyal Bilimler Enstitüsü, İşletme Anabilim Dalında 2019 yılında danışmanlığını Dr. Öğr. Üyesi Nil Esra DAL' in yaptığı Fikriye YEŞİLOT tarafından hazırlanan 'Müşteri Deneyimi Oluşturma ve Deneyimsel Pazarlama: Iyaşpark AVM Müşterileri ile Bir Araştırma' isimli yüksek lisans tezinden üretilmiştir.

* Sorumlu yazar/Corresponding author

E-mail/e-ileti: fkrygztp@gmail.com 
U testi yapılmıştır. Verilerin normal dağılmadığı tespit edilmiştir. Analiz sonucunda, stratejik deneyimsel pazarlama boyutları ile Iyaşpark Alışveriş Merkezi deneyimini tavsiye etme ya da tavsiye etmeme arasında istatistiksel olarak anlamlı bir farklılık tespit edilmiştir. Ayrıca, evli ve bekâr katılımcılar arasında tüketicinin duygu ve hislerine yönelen duygusal deneyim boyutunda da istatistiksel olarak anlamlı farklılık bulunmaktadır.

Anahtar kelimeler: Deneyimsel Pazarlama, Deneyim Ekonomisi, Deneyim, Müşteri Deneyimi, Alışveriş Merkezi.

\title{
Experiential Marketing and Creating Customer Experience: A Research on Iyaspark Shopping Mall Customers
}

\begin{abstract}
Current technological and economic developments have led to many changes in marketing industry. The difference between today's customer's needs and wants is gradually increasing. Functional benefits expected from products and services are replaced by emotional and symbolic values. Providing only service to the customer is insufficient in an intense competitive environment. Rather than buying products and services that provide benefits, the customer tends to provide emotion-oriented customer experience. With the individualization of services for customers, the concept of experience economy has developed. Thanks to the experience economy, experiential marketing has emerged. Today's most popular venues, shopping malls have become the socialization and entertainment centers that provide the consumer with experience, ensure that the consumer has a good time. As a result, Shopping Malls give importance to experiential marketing and customer experiences in a highly competitive environment.
\end{abstract}

The subject of the research is to determine whether or not customers will recommend the mall experience by revealing the strategic experiential marketing dimensions that have an impact on the customer experience. The aim of the research is to determine the shopping habits of shopping mall customers and to examine the shopping experiences in terms of experiential marketing and to examine them in the context of strategic experiential marketing dimensions.

In the research, online questionnaire was applied to 483 people who shop from Iyaşpark shopping center. Normality test, reliability analysis, frequency analysis, Kruskal Wallis test and Mann Whitney $U$ test are performed in the research. According to results, the data set is not 
normally distributed. As a result of the analysis, a statistically significant difference was found between strategic experiential marketing dimensions and Iyaşpark Shopping Center experience recommendation or not. In addition, there is a statistically significant difference between the married and single participants in the dimension of emotional experience directed towards the emotions and feelings of the consumer.

Keywords: Experiential Marketing, Experience Economy, Experience, Customer Experience, Shopping Mall.

\section{GİRIŞ̧}

Küreselleşmenin hız kazanması ve değişen teknoloji pazarlamaya yeni bir bakış kazandırmıştır. İşletmelerin yoğun rekabet ortamında ayakta kalmaları giderek güçleşmektedir. Bu duruma, değişen müşteri istek ve ihtiyaçları eklenince yeni pazarlama stratejileri gelişmiştir. Müşteriye önem veren, müşterinin duygularına yönelen ve kalıcı deneyimler amaçlayan deneyimsel pazarlama kavramı ortaya çıkmıştır. Deneyimsel pazarlama odak noktasına müşterisini alarak farklı deneyimler yaşatmayı öngörmektedir. Günümüzde özellikle hizmet ekonomisi yerini müşteriye yaşatılan duygu ve deneyim ekonomisine bırakmaktadır.

Deneyim ekonomisinin gelişmesine katkıda bulunan son dönemdeki teknolojik gelişmeler, tüketim olgusu, müşterinin duygu ve düşüncelerinin önemsenmesi olarak karşımıza çıkmaktadır. Günümüzdeki gelişmelere bağlı olarak çeşitli hizmet sektörlerinde önem kazanan deneyimsel pazarlama uygulamaları birçok işletme tarafından uygulanmaktadır. Günümüzde deneyimsel pazarlamanın özelliklerini uygulayan AVM'ler müşteriye deneyim sunan, eğlence ve hoş vakit geçirilen deneyim merkezleri haline gelmektedir. AVM'ler deneyimsel pazarlama uygulamalarını ele alarak müşteriye değer sunan ve stratejik deneyimsel pazarlama boyutlarının özelliklerini kullanan mekânlar olmuştur.

Alışveriş merkezleri sadece ürün ve hizmet satmak yerine müşterinin yaşadığı stratejik deneyimsel pazarlama boyutlarına ve müşteri deneyimlerine önem vermektedir. Müşteri odaklı bir yaklaşımı benimseyerek müşterinin istek ve ihtiyaçlarına cevap vermeyi amaçlamaktadır.

Araştırmanın konusu, müşteri deneyimi üzerinde etkili olan stratejik deneyimsel pazarlama boyutlarını ortaya koyarak müşterinin alışveriş merkezi deneyimini tavsiye etme ya da tavsiye etmeme durumunu tespit etmektir. Çalışmada, AVM müşterilerinin alışveriş alışkanlıklarını tespit edip, alışveriş deneyimlerini deneyimsel pazarlama açısından ele alarak stratejik deneyimsel pazarlama boyutları bağlamında incelemek amaçlanmıştır. 


\section{KAVRAMSAL ÇERÇEVE}

Çalışmada deneyimsel pazarlama ile ilgili birtakım kavramların açıklanmasına yer verilmiştir. Deneyim ekonomisi ve deneyimsel pazarlama başlığı atında deneyim kavramı, deneyim ekonomisi, deneyimsel pazarlama kavramı, stratejik deneyimsel pazarlama boyutları ve uygulama aşamaları ele alınmıştır. Müşteri deneyimi başlığı altında ise; müşteri deneyimi kavramı, müşteri deneyimi aşamaları, deneyim sağlayıcılar, müşteri deneyimi tasarlanması ve müşteri deneyimini etkileyen faktörler açıklanmıştır.

\subsection{Deneyim Ekonomisi ve Deneyimsel Pazarlama}

Günümüzde rekabet etmek gittikçe zorlaşmaktadır. İşletmelerin sadece ürün, fiyat, tutundurma ve dağıtım gibi pazarlama karma öğelerinde farklılık yaratmasının yeterli rekabet avantajı sağlamayacağını, deneyim üzerine odaklanıp farklılaşma yaratarak rekabet avantajının arttırılabileceğini söylemek mümkündür. Alan yazınında deneyim kavramının farklı tanımlarına rastlanmaktadır.

Türk Dil Kurumu sözlüğünde deneyim, 'Bir kimsenin belli bir sürede veya hayat boyu edindiği bilgilerin tamamı, tecrübe' olarak tanımlanmaktadır (www.tdk.org.tr, 2012). Rekabetin artması, tüketicilerin taleplerindeki değişmeler, deneyimin önem kazanmasına neden olmuştur. Deneyim konusu anlaşılması zor bir kavram olarak karşımıza çıkmaktadır. İngilizce literatüründe “experience”'olarak adlandırılır (Pine ve Gilmore, 1999: 90). Deneyim kavram1, 1982 yılında ilk defa Holbrook ve Hirschman'ın makalesinde tüketici davranışı alan yazınına kazandırılmıştır. Holbrook ve Hirschman deneyimi; 'ürün ya da hizmetin tüketimine bağlı olarak ortaya çıkan durum' olarak tanımlamışlardır (Morgan, 2007: 366). Schmitt deneyimi satın almaya karar vermeden önceki aşamalar ve satın alma sonrasında oluşan çeşitli faaliyetler olarak ifade etmektedir (Schmitt (1999: 59)'dan Aktaran, Baştuğ (2018: 2). Yoğun rekabet ortamında ürünleri sadece hizmetlerle desteklemek ya da farklı bir hizmet sunmak yetersiz kalmaktadır. İşletmelerin ekonomik bir değer ya da tüketici değeri yaratabilmesi için "eşsiz, unutulmaz bir deneyim" yaratarak farklılık sağlaması ve tüketici sadakatini yaratması kaçınılmaz olmuştur (Günay, 2008: 182). Gelişen ve değişen teknolojilerle birlikte müşterilerin istek ve ihtiyaçları da değişmektedir. Buna bağlı olarak deneyim ekonomisi gelişmiştir (Çeltek, 2010: 21). Deneyim ekonomisi kavramı Joseph Pine ve James Gilmore tarafından 1998 yılında ortaya atılmıştır. Pine ve Gilmore (1998) deneyimin kişiye özgü olduğunu belirterek işletmelerin tüketicilere sunduğu ürünleri metalar, mallar, hizmetler ve deneyimler olarak dört 
ayrı ekonomik sunu olarak değerlendirmiştir (Tsai, 2005: 435-436). Her ekonomik sunu, işlev, nitelik, özellik, arz yöntemleri, talep yöntemleri alıcı ve satıcıda oluşturdukları kimlikleri ile birbirinden farklılaşmaktadır (Konuk, 2014: 10).

Tablo 1. Ekonomik ayrımlar

\begin{tabular}{|c|c|c|c|c|}
\hline Ekonomik sunu & Metalar & Mallar & Hizmetler & Deneyimler \\
\hline Ekonomi & Tarım & Sanayi & Hizmet & Deneyim \\
\hline Ekonomik işlev & $\begin{array}{c}\text { Doğadan } \\
\text { Elde etme }\end{array}$ & Üretme & Sağlama & Sahneleme \\
\hline Sununun niteliği & $\begin{array}{c}\text { Misliyle } \\
\text { ölçülebilir }\end{array}$ & Somut & Soyut & Akılda kalıcı \\
\hline Ana vasıf & Doğal & Standart & Siparişe uygun & Kişisel \\
\hline Arz yöntemi & $\begin{array}{c}\text { Partiler halinde } \\
\text { depolama }\end{array}$ & $\begin{array}{c}\text { Üretim sonrası } \\
\text { stoklama }\end{array}$ & $\begin{array}{c}\text { Talep üzerine } \\
\text { sağlama }\end{array}$ & $\begin{array}{c}\text { Belli bir sürede } \\
\text { ortaya çıma }\end{array}$ \\
\hline Satıcı & Tüccar & Üretici & Sağlayıcı & Sahneleyici \\
\hline Alıcı & Pazar & Kullanıcı & Müşteri & Misafir \\
\hline Talep faktörleri & Nitelikler & Özellikler & Yararlar & Algılar \\
\hline
\end{tabular}

Kaynak: Pine ve Gilmore, 2012: 37

Günümüz tüketicisi çok fazla sayıda ürün ve hizmet reklamına maruz kalmaktadır. Fakat ilginç, akılda kalıcı pazarlama deneyimlerini diğerlerinden kolayca ayırt edip hatırlamaktadır. $\mathrm{Bu}$ yüzden işletmeler rekabet ortamında farklı olabilmek için tüketicilere unutulmaz deneyimler yaşatmaya odaklanarak deneyimsel pazarlamaya yönelmişlerdir.

Deneyimsel pazarlamanın gelişimi kesin olarak ilk kez 1998 yılında, Pine ve Gilmore aracılığıyla Harvard Business Review dergisinde yayımlanan "Welcome to the Experıence Economy', adlı makalede ortaya atılmıştır (Kalyoncuoğlu, 2018: 74).

Daha sonra 1999 yılında Schmitt deneyimsel pazarlama kavramını yeni pazarlama anlayışının kalbine yerleştirmiştir. Schmitt, deneyimsel pazarlama kavramının ortaya çıkışında üç önemli gelişmeden bahsetmektedir. Birincisi, bilgi teknolojilerinin her yerde bulunması ikincisi, marka kavramının gün geçtikçe ilerlemesi ve pazarlama faaliyetlerinin markaya dönüşmesi, üçüncüsü, iletişim ve eğlencenin her temas noktasında mevcut olmasıdır. Bu üç faktör işletmeleri müşteri dünyası analiziyle başlayan deneyim uygulamalarına yöneltmektedir (Same, 2012: 7). Schmitt deneyimsel pazarlamay1, ürün ve hizmetlerin müşteriye sağladığ fonksiyonel özellik ve faydadan ziyade müşteri deneyimlerine odaklanan bütüncül bir yaklaşım olarak ifade etmektedir. Schmitt'e göre tüketiciler artık duygularına hitap eden, kalplerine dokunan, düşünmeye teşvik eden iletişim ve pazarlama kampanyaları istemektedirler (Konuk, 
2014: 13; Kalyoncuoğlu, 2018: 74-75). Geleneksel pazarlama anlayışından çok farklı olan deneyimsel pazarlama olumlu ve zevkli deneyim yaşatmaya odaklanmaktadır. Geleneksel pazarlamada özellik ve fayda ön planda iken deneyimsel pazarlamada müşteri deneyimi önemlidir (Schmitt, 1999: 58). Deneyimsel pazarlamanın amacı, geleneksel pazarlama anlayışından sıyrılıp müşterinin kalbine dokunan, huzur veren, eğlendiren, eşsiz deneyimler oluşturarak pazarda rekabet avantajı sağlamaktır. Deneyimsel pazarlama işletmeyi müşterinin gözünden yönetmeyi amaçlayan bir stratejidir. Müşteriye sağlanan tüm değerleri, değer sağlamada gerekli unsurların birlikte yönetimini ifade eder. Deneyimsel pazarlamanın odak noktası müşteriye sürekli değer sağlamaktır (Arussy, 2007). Schmitt deneyimsel pazarlamanın dört temel özelliği olduğunu vurgulamıştır. Deneyimsel pazarlamanın özellikleri geleneksel pazarlama özelliklerinden farklılık göstermektedir. Deneyimsel pazarlamanın odak noktası müşteri deneyimleridir. Schmitt deneyimsel pazarlamanın özelliklerini müşteri deneyimi üzerine odaklanma, bütünsel bir deneyim olarak tüketime odaklanma, müşterilerin rasyonel ve duygusal olması ve yöntem ve araçların eklektik olması bağlamında ele almaktadır (Schmitt, 1999: 56):

Müşteri deneyimi üzerine odaklanma, müşterinin duygusuna ürün ve hizmette yaşamak istediği deneyimlere odaklanmaktadır. Bütünsel bir deneyim olarak tüketime odaklanma, deneyimsel pazarlamada müşteriler satın aldıkları ürün ve hizmeti ayrı ayrı düşünmemektedir. Müşteriler için önemli olan ürün ve hizmetlerin bütününden aldıkları haz ve keyiftir (Başar, 2015: 9). Müşterilerin rasyonel ve duygusal olması, geleneksel pazarlamaya göre müşteriler rasyonel kararlar vermektedir fakat deneyimsel pazarlamaya göre duyguları ve düşüncelerini ön plana çıkararak duyuları ile hareket etmektedirler. Yöntem ve araçların eklektik olması, deneyimsel pazarlama yöntemleri ve araçları çeşitli ve çok yönlüdür. Her bireye özgü davranış eğilimi vardır (Argan, 2007: 74-75).

\subsection{Stratejik Deneyimsel Pazarlama Boyutları}

Müşterilerine eşsiz ve unutulmaz deneyim yaşatmak isteyen işletmeler, deneyim boyutları aracılığıyla bu süreci planlamaktadırlar (Güney, 2015: 18). Müşterilerin yaşayacağı beş ayrı deneyim Schmitt (1999: 54)'e göre; duyusal deneyim, duygusal deneyim, düşünsel deneyim, davranışsal deneyim ve ilişkisel deneyim olarak tanımlanmıştır. 
Tablo 2. Deneyimsel pazarlamanın boyutları

\begin{tabular}{|l|l|l|}
\hline Deneyim Boyutu & Deneyim Eylemi & Müşteri Deneyimi \\
\hline Duyusal & Algılamak & Beş duyuya hitap eder. \\
\hline Duygusal & Hissetmek & Hislere ve ruh haline hitap eder. \\
\hline Düşünsel & Düşünmek & Yaratıcılık ve bilişsel fonksiyonlara hitap eder. \\
\hline Davranışsal & Faaliyette Bulunmak & Davranışlara ve yaşam tarzına hitap eder. \\
\hline İlişkisel & İlişkilendirmek & Kültürel ve sosyal gruplara hitap eder. \\
\hline
\end{tabular}

Kaynak: Pine, Gilmore (2012) ve Genç'den (2009: 69) derlenmiştir.

Duyusal boyut, duyulara hitap ederek müşterinin duyma, dokunma, görme gibi duyularını uyararak duyusal deneyim yaşatmayı hedeflemektedir. Duyusal boyut genellikle deneyim esnasında karşılaşılan ilk deneyim boyutudur (Tsaur vd, 2006: 52). Duygusal deneyim boyutu ise; hafif duygulardan, güçlü duygulara kadar farklılık gösteren tüketicilerin duygularına ve hislerine hitap eden deneyim boyutudur. Güçlü duyguları oluşturmak için müşterileri anlamak, hangi uyarıcının hangi duyguyu oluşturduğunu analiz etmek gerekmektedir (Mashingaidze, 2014: 55). Düşünsel deneyim boyutu, tüketicilerin, işletme ve ürünler hakkında detaylı ve yaratıcı düşünmesini desteklemektir. Düşünsel deneyim, tüketicileri düşündürerek yaratıcılığa yönlendirdiği gibi onları düşünmeye ve problem çözmeye yönlendirir. Amaç, tüketicinin düşüncelerinin harekete geçirilmesidir. İşletme ve markası hakkında olumlu düşünülmesi sağlanmaya çalışılmaktadır (Kır, 2014: 117). Davranışsal deneyim, müşterilerin yaşam tarzlarını inceleyerek onların hayatlarına heyecan katmak ve müşteriye sunulabilecek deneyimleri tasarlamaktır. Davranışsal deneyim müşterilerin yaşam tarzlarını inceleyerek müşterilerin istediği özellikte ürün ve hizmeti sunmaktadır. Davranışsal deneyim, diğer deneyim boyutlarının bütünüdür (Deligöz, 2014: 62). İlişkisel deneyim, günümüzde işletmelerin çok önemli bir amacı vardır. Günümüz işletmelerinin amacı, müşteriyle ilişki kurabilmek, her bireyin farklılığına eşsizliğine, kişiselliğine vurgu yapma çabası içerisinde olmaktır. Deneyim ve ilişki ayrılmaz bir bütündür. İlişkiyi sürekli tutmak, güvene dayalı ilişki içerisinde tüketici isteklerine ve beklentilerine cevap vermek önemli faktör olmaktadır (Batı, 2017: 113). İlişkisel deneyim diğer deneyim boyutlarını içeren sosyal kimlik ihtiyacı, ait olma isteği gibi faktörleri yaşatmayı amaçlamaktadır.

\subsection{Deneyimsel Pazarlama Uygulama Aşamaları}

Deneyimsel pazarlamanın uygulanması dört aşamadan oluşmaktadır. Bu aşamalar; müşteri analizi, deneyimsel platformun oluşturulması, müşteri etkileşiminin oluşturulması, marka deneyiminin oluşturulması şeklindedir (Schmitt, 2003: 20). 
Müşteri analizi, müşteri analizi müşteri beklenti ve ihtiyaçlarının, kişiliklerinin, yaşam biçimlerinin analizini içerir (Tunç, 2017: 29). Deneyimsel platformun oluşturulması, işletmenin veya markanın konumlanacağı bir zemin (deneyimsel platform) oluşturulması gerekmektedir. Marka deneyiminin oluşturulması, deneyim yaşatan ürün ve hizmetin her alanda tasarımını ifade etmektedir (Özgören, 2013: 3). Müşteri etkileşiminin meydana getirilmesi, müşteri ile etkileşimin olduğu noktaların belirlenmesi ve geliştirilmesi sürecidir (Schmitt, 2003: 28).

\subsection{Müşteri Deneyimi}

Müşteri deneyimi ürün ve hizmetlerin sağladığı faydayı duyusal yönleriyle birlikte düşünülmesini sağlayan bütüncül bir kavramdır (Berry vd, 2002: 89). Müşteri deneyimi, tüm temas noktalarında ortaya çıkan işletmeye verilen toplam değeri ifade etmektedir. Temas noktaları müşterinin ürün veya hizmeti satın alma öncesi başlayan satın alma sırasında devam eden ve satın aldıktan sonraki süreçlerde müşteri düşüncelerini kapsar. Müşteri deneyimi günümüzde işletmeler için önemli bir rekabet avantajı haline gelmiştir. İşletmeler sadece ürün ve hizmet sunmak yerine müşterinin duyguları ile zenginleştirilmiş bir deneyim sunmak durumunda kalmaktadırlar (Meyer ve Schwager, 2007: 1-12). Müşteri deneyimi konusunda lider olmak isteyen işletmeler şu adımlara önem vermek zorundadır (Luigi vd., 2012: 56):

> Müşteri ihtiyaçlarını önemsemelidir.

> Müşteriyle kurulan ilişkinin hatırlanabilir olması gerekmektedir.

Müşteri deneyimini işletme kültürüne yerleştirmek gerekmektedir.

\subsection{Müşteri Deneyimi Aşamaları}

Tüketici yaşamı boyunca ailesinden, çevresinden öğrenme eylemini gerçekleştirir. Tüketim deneyimi de ailede başlayarak tüketim ve alışveriş alışkanlıkları çevreyle, teknolojinin gelişmesiyle farklılık gösterir. Bugünün tüketicisi kendine yeni alışveriş mekânlarında alışveriş ve eğlenceyi birleştirerek deneyim yaşamayı amaç edinmektedir. Birey daha sonra büyüdükçe alışverişe olan davranışı ve tutumu çevresiyle birlikte değişime uğramaktadır. Her birey farklı bir yaşam tarzı ile yetiştiğinden ürün ve hizmetlerden beklentisi ve deneyim algısı da farklı olacaktır (Torlak vd., 2007: 52-54).

Müşteri deneyimi aşamaları beklentilere şekil vermek, satın alma öncesi, satın alma etkileşimi, ürün/hizmet tüketimi etkileşimi, deneyim sonrası değerlendirmeden oluşmaktadır (Shaw ve Ivens, 2002: 23-55, Brakus vd., 2009: 54): 
> İlk aşamada, tüketim ile ilgili beklentiler şekillenmektedir. İlk aşamada iletişim ve ikna çabaları yoğun olarak kullanılmaktadır. Beklentilerin şekillenmesinde etkili olan unsurlar marka imajı, reklamlar, ağızdan ağıza iletişim, deneyimi yaşayan diğer bireylerin deneyimleri ve bireyin geçmişte yaşadığ büyük rol oynamaktadır.

> İkinci aşamada, satın alma öncesi etkileşimin gerçekleştiği aşamadır. Tüketicilerin satın alma kararını verdikleri ana kadar yapmış oldukları inceleme ve araştırmaları kapsar. $\mathrm{Bu}$ süreçte tüketiciler işletmenin sitesi, katalog inceleme satış elemanlarına danışma, satın alacakları yerin atmosferi, fiyat karşılaştırması yapma gibi davranışlarda bulunmaktadırlar.

> Üçüncü aşama, satışın ve tüketim deneyiminin en önemli kısmı gerçekleşmektedir. Satın alma faaliyeti başlamaktadır. Satın alma ile tüketim deneyiminin önemli kısmı gerçekleşmiştir.

$>$ Dördüncü aşamada, ürünün kullanıldığı ve tüketildiği aşamadır. Müşteri deneyimini kapsayan en geniş bölümdür. Ürün veya hizmetin tüketilmesiyle tüketici deneyimi meydana gelir.

Tüketici deneyiminin son aşaması deneyim değerlendirme ve karşılaştırma aşamasıdır. Bu aşamada tüketici yaşadığı deneyimi, beklentileriyle karşılaştırır. Tüketici beklentisini ve deneyimini gözden geçirerek uyumlaştırma yapmaktadır.

\subsection{Deneyim Sağlayıcılar}

Schmitt (1999), stratejik deneyim boyutlarının tüketiciler için unutulmaz deneyim sunabilmesi için “Experience Providers" deneyim sağlayıcı (ExPros) araçların kullanılmasını öngörmektedir. Stratejik deneyimsel boyutun uygulanmasında müşteri deneyiminin kalıcı ve tutarlı olabilmesi için deneyim sağlayıcılardan yararlanmak gerekmektedir. Deneyim sağlayıcıları; iletişim, görsel ve sözel kimlik, marka bilinirliği, çevresel faktörler, web sayfaları ve elektronik ortam, işletme çalışanları olarak belirtilmektedir. İletişim, gazeteler, radyo, dergiler, haberler, reklamlar ve halkla ilişkiler faaliyetleridir. Görsel ve sözel kimlik, isim, logo, renkler, ambalaj ve slogan görsel ve sözel kimliği oluşturan deneyim sağlayıcılardır. Marka bilinirliği, sponsorluklar, organizasyonlar, ortaklıklar, lisans ve filmlerde ürün yerleştirme çabalarını içermektedir. Çevresel faktörler, deneyim sağlayıcı olarak çevresel faktörler başlığı 
altında binaları, ofisleri, fabrikaları, perakendecileri ve tüm ticari alanları ele almak mümkündür (Varinli, 2008: 44).

\subsection{Müşteri Deneyimi Tasarlanması}

İşletmelerin sürekliliğini sağlayabilmesi, yenilikçi ortama ayak uydurabilmesi için müşterilerine eşsiz deneyimler sunması gerekmektedir. $\mathrm{Bu}$ yüzden müşteri deneyimi günümüzde rekabet avantajı elde etmek için giderek önemi artan bir faktördür. Müşteriler kendilerini değerli k1lan ürün ve hizmetten faydalanmak istemektedirler. Bu noktada tüketicinin davranışlarının analiz edilmesi, ihtiyaçlarının belirlenmesi ve tüketicinin olumlu duygularını uyandıran deneyimlerin tasarlanması işletmelere rekabet avantajı sağlamaktadır. İşletmenin kültürüne uygun doğru yer ve zamanda doğru deneyimlerin yaşatılması işletmenin büyümesini sağlarken marka imajını da kuvvetlendirmektedir (Dirsehan, 2012: 55).

Deneyim sağlayabilmek için olması gereken özellikler vardır. Shaw ve Ivens (2002) tüketici deneyimi oluşturmanın yedi felsefesi olduğunu belirtmektedirler (Shaw ve Ivens, 2002: 10-11; Kır, 2014: 100-101):

> İşletmeler ayakta kalabilmek rekabet avantajı elde etmek için kaynak oluşturmaktadır. İşletmeler gelişim ve değişimleri için yeterli kaynak ayırmalıdır.

$>$ İyi müşteri deneyimi, tüketicilerin fiziksel ve duygusal beklentilerine doğru cevap vermekle sağlanır.

> Planlanmış duyguların harekete geçirilmesine odaklanmalıdır.

> İyi müşteri deneyiminde müşteriler işletmelerin hep odak noktasında olmalıdır. Müşteri beklentisi göz önünde bulundurulmalıdır.

$>$ İyi bir müşteri deneyimi için müşterinin ürün ve hizmet hakkında geri bildirimini almak gerekmektedir.

$>$ İyi müşteri deneyimi, giderleri ve maliyetleri azaltarak işletmeye kar artışı sağlamalıdır.

$>$ İyi müşteri deneyimi, markanın ve işletmenin müşteriye her yerde özel deneyim sunmasıyla oluşur.

İşletmelerin müşteri deneyimini oluştururken deneyimi olumlu ya da olumsuz etkileyebilecek faktörlere önem vermesi gerekir. Müşteri deneyimini etkileyen faktörler, ilk izlenimin olumlu olması, duyuların harekete geçirilmesi, ortam ve ürün teması, çalışanların davranışları ve ürün özelliklerinden oluşmaktadır (Demirdöven, 2018: 120; Çeltek, 2010: 92). 
İlk izlenimin olumlu olması, işletmenin müşteriye ilk temas ettiği nokta deneyimin bütünü üzerinde etkilidir. İşletmeler müşteriyle ilk karşılaşma anına önem vermektedir. İlk izlenim ne kadar olumlu ise müşteri işletmeye yakınlaşacaktır ve işletmeye olan bağlılığı artacaktır. Duyuların harekete geçirilmesi, duyular koklama, dokunma, tatma, görme, duyma uyaranlarının tüketiciye her temas noktasında dengeli ve eşit verilmesi ile harekete geçirilmektedir. Duyusal uyaranlar karşılıklı uyum içinde olmalıdır (Odabaşı ve Oyman, 2005: 264). Ortam ve ürün teması, müşteri deneyimini tasarlarken kapı girişinden başlayarak koridorlar, mağazanın iç görünümü, yemek bölümü gibi alanlar deneyimin sahnesini oluşturmaktadır. Müşteriyi harekete geçiren olumlu bir ortamın varlığı satın almayı harekete geçirerek mağazadaki dolaşma süresini arttırmıştır. Müşterinin alışveriş yaptığı ortamı; mağazaların dekoru, ürün sunumları, renkler, aydınlatma, havalandırma, koku, müzik, çalışanların tutumları ve alışveriş yapan diğer müşteriler oluşturmaktadır (Yıldırım, 2015: 64). Çalışanların davranışları, çalışanlar işletmeyi temsil ettiğinden dış görünüşü, davranışları, markayla uyumlu olmalıdır. Çalışanların olumsuz davranışı müşterinin yaşayacağı deneyimin bütününü etkilemektedir (Karakaşoğlu ve Arslan, 2016: 225). Ürün özellikleri, marka ismi, ambalaj, dizayn, renk, şekil ürünün fiziksel özellikleridir. Ürünün dizaynı, fiziksel özellikleri ve görünümü deneyimi etkileyen faktörlerdendir (Arslan, 2004: 181).

\section{TASARIM VE YÖNTEM}

Çalışmanın tasarım ve yönteminde araştırmanın konusu, araştırmanın amacı, kapsamı ve kısıtı, araştırmanın ana kütlesi ve örneklem seçimi, veri toplama yöntemi ve anket formunun hazırlanması, araştırmanın hipotezleri açıklanmıştır.

\subsection{Araştırmanın Konusu}

Araştırmanın konusu, müşteri deneyimi üzerinde etkili olan stratejik deneyimsel pazarlama boyutlarını ortaya koyarak müşterinin alışveriş merkezi deneyimini tavsiye etme ya da tavsiye etmeme durumunu incelemektir.

\subsection{Araştırmanın Amacı, Kapsamı ve Kısıtı}

Araştırmanın amacı, AVM müşterilerinin alışveriş alışkanlıklarını tespit edip, alışveriş deneyimlerini deneyimsel pazarlama açısından ele alarak stratejik deneyimsel pazarlama boyutları bağlamında incelemektir. Ayrıca araştırmaya katılanların anketi içtenlikle cevapladıkları varsayılmıştır. Alışveriş öncesinde, esnasında ve sonrasında tüketicilerin izlenmesinin zorluklarından ve AVM yönetiminden gerekli izinlerin alınmasının 
güçlüklerinden dolayı anketin çevrimiçi olarak yapılmasına karar verilmiştir. Bu kapsamda araştırmanın temsil etme yeteneğinin sınırlı olacağı ve genellenemeyeceği düşünülmektedir.

Ayrıca çalışmada kolayda örnekleme yönteminin düşük maliyetli ve uygulanmasının en kolay olması araştırmanın diğer kısıtlarını oluşturmaktadır (İslamoğlu ve Alnıçık, 2016: 78). Araştırmada örneklemi oluşturan katılımcılara ulaşmanın zorluğundan dolayı kolayda örnekleme yöntemi ve çevrimiçi anket metodunun uygulanmıştır. Araştırmada Iyaşpark alışveriş merkezinden en az bir kez alışveriş yapmış olan katılımcılara anket uygulanmıştır.

\subsection{Araştırmanın Ana Kütlesi ve Örneklem Seçimi}

Araştırmanın örneklemi, Iyaşpark alışveriş merkezinden en az bir kez alışveriş yapan tüketicilerden oluşmaktadır. Evreni ise Iyaşpark alışveriş merkezinden alışveriş yapan tüketici kitlesidir. Sosyal bilim araştırmalarında en yaygın, uygulaması en kolay olarak bilinen örneklem tekniği kolayda örnekleme yöntemi kullanılmıştır. Gürbüz ve Şahin (2015: 126127)'e göre \%95 güvenilirlik düzeylerinde 250 bin ile 10 milyon arasındaki evren büyüklüklerine 384 örneklemin yeterli olacağını belirtmişlerdir. Araştırmada 483 katılımcıya çevrimiçi anket uygulanmıştır.

\subsection{Veri toplama Yöntemi ve Anket Formunun Hazırlanması}

Araştırma verilerinin toplanmasında nicel bir yöntem olan çevrimiçi anket yöntemi kullanılmıştır (Gegez, 2007: 87). Anket verileri 27 Mart 2018 - 29 Nisan 2018 tarihleri arasında toplanmıştır. Anket formu üç bölümden oluşmaktadır.

Anketin birinci bölümünde, Iyaşpark Alışveriş Merkezi alışveriş alışkanlığı hakkında sorulardan oluşmaktadır. Anketin birinci bölümündeki sorular, “AVM Tüketici Alg1 Araştırması: AVM Ziyaretçisi Büyüteç Altında: Alışveriş Merkezi Yatırımcıları Derneği (2010)" isimli çalışmadan yararlanılarak oluşturulmuştur.

Anketin ikinci bölümde katılımcıların alışveriş merkezinde alışveriş yaparken yaşadıkları deneyimlere dayanarak cevaplandırılacak sorular yer almaktadır. Katılımcıların ölçek maddelerine katılım düzeyi 5'li likert tipi (1-Kesinlikle Katılmıyorum, 2-Katılmıyorum, 3-Ne Kat1lyorum, $\mathrm{Ne}$ Kat1lmiyorum, 4-Kat1lyoum, 5-Kesinlikle Kat1lyorum) değerlendirmeyle ölçülmüştür. Anketin ikinci bölüm soruları, müşteri deneyimi ölçeği Alemdar (2010), Lin vd., (2009), Brakus vd., (2009), Başar (2015), Kara ve Çiçek (2015) yararlanarak oluşturulmuştur. 
Anket formunun üçüncü bölümünde ise, katılımcıların demografik bilgileri hakkında sorular yer almaktadır. Bu bölümde tüketicilerin yaş, cinsiyet, eğitim durumu, meslek ve kişisel gelirlerine yönelik bilgiler toplanmıştır. Anket formu toplamda 40 sorudan oluşmaktadır.

\subsection{Araştırmanın Hipotezleri}

Nicel araştırma yönteminin kullanıldığı çalışmanın hipotezleri şöyledir:

H1: Katılımcıların yaşadığı duyusal deneyimleri ile Iyaşpark alışveriş merkezi deneyimi arasında istatistiksel olarak anlamlı bir farklılık vardır.

H2: Katılımcıların yaşadığı duygusal deneyimleri ile Iyaşpark alışveriş merkezi deneyimi arasında istatistiksel olarak anlamlı bir farklılık vardır.

H3: Katılımcıların yaşadığı düşünsel deneyimleri ile Iyaşpark alışveriş merkezi deneyimi arasında istatistiksel olarak anlamlı bir farklılık vardır.

H4: Katılımcıların yaşadığı davranışsal deneyimler ile Iyaşpark alışveriş merkezi deneyimi arasında istatistiksel olarak anlamlı bir farklılık vardır.

\section{VERILERIN ANALIZİ VE BULGULAR}

Araştırma sürecinde anket formlarından toplanan veriler amaca uygun istatistiksel paket programında analiz edilmiştir. Araştırmada; güvenilirlik analizi, frekans analizi, tanımlayıcı istatistikler, normallik testi, Mann Whitney U Testi ve Kruskal Wallis Testi yapılmıştır.

\subsection{Güvenilirlik Analizi}

Araştırmada ölçeklerin güvenilirliklerini test etmek için Cronbach's Alpha yöntemine başvurulmuştur. Cronbach's Alpha değeri 0 ile 1 arasında bir değer almaktadır. Ayrıca kullanılan ölçeğin güvenilir olması için alfa katsayısının 0.80 ve üzerinde olması gerekmektedir (Kalayc1, 2014: 405).

Tablo 3. Güvenilirlik analizi

\begin{tabular}{|c|c|}
\hline Cronbach's Alpha & Madde Sayıları \\
\hline 0.956 & 25 \\
\hline
\end{tabular}

Araştırmada yer alan 25 maddelik müşteri deneyimi ölçeğine güvenilirlik analizi yapılmıştır. Analiz sonucu Cronbach Alpha katsayısı 0,95 bulunmuştur. Bu değerin 0,80'den büyük olması, ölçeğin yüksek derecede güvenilir olduğunu göstermektedir. 


\subsection{Frekans Analizi}

Katılımcıların frekans analizine yönelik bulgular Tablo 4' de yer almaktadır. $\mathrm{Bu}$ doğrultuda katılımcıların \%73,5' i kadın, \%26,5' i erkektir. Katılımcıların \%37,5'ini 26-35 yaş grubunda olduğu, katılımcıların \%50,3'ünün evli olduğu ve \%45,3’ünün eğitim durumunun lisans seviyesinde olduğu görülmektedir. Ayrıca katılımcıların \%28,8'inin öğrenci olduğu ve \%43,52'inin aylık gelirinin 1600 TL ve altında olduğu belirlenmiştir.

Tablo 4. Katılımcıların demografik özelliklerine göre dağılım

\begin{tabular}{|c|c|c|}
\hline Cinsiyet & Frekans & Yüzde\% \\
\hline Kadın & 355 & 73,5 \\
\hline Erkek & 128 & 26,5 \\
\hline Toplam & 483 & 100,0 \\
\hline Yaş & Frekans & Yüzde\% \\
\hline 18 yaş ve altı & 26 & 5,4 \\
\hline $19-25^{3}$ & 135 & 28,0 \\
\hline $26-35$ & 181 & 37,5 \\
\hline $36-45$ & 78 & 16,1 \\
\hline $46-55$ & 53 & 11,0 \\
\hline 56 ve üzeri & 10 & 2,1 \\
\hline Toplam & 483 & 100,0 \\
\hline Medeni Durum & Frekans & Yüzde\% \\
\hline Evli & 243 & 50,3 \\
\hline Bekar & 240 & 49,7 \\
\hline Toplam & 483 & 100,0 \\
\hline Eğitim Düzeyleri & Frekans & Yüzde\% \\
\hline İlkokul & 8 & 1,7 \\
\hline Ortaokul & 10 & 2,1 \\
\hline Lise & 101 & 20,9 \\
\hline Önlisans & 77 & 15,9 \\
\hline Lisans & 219 & 45,3 \\
\hline Yüksek Lisans & 50 & 10,4 \\
\hline Doktora & 18 & 3,7 \\
\hline Toplam & 483 & 100,0 \\
\hline Meslek & Frekans & Yüzde\% \\
\hline Öğrenci & 139 & 28,8 \\
\hline Nitelikli uzman meslekler & 91 & 18,8 \\
\hline Özel sektör çalışanı & 78 & 16,1 \\
\hline Kamu çalışanı & 33 & 6,8 \\
\hline Serbest Meslek & 41 & 8,5 \\
\hline İşsiz & 17 & 3,5 \\
\hline Ev hanımı & 69 & 14,3 \\
\hline Emekli & 15 & 3,1 \\
\hline Toplam & 483 & 100,0 \\
\hline Kişisel Net Gelir & Frekans & Yüzde\% \\
\hline 1600 TL ve alt1 & 210 & 43,5 \\
\hline $1601-2600 €$ & 85 & 17,6 \\
\hline 2601-3600 & 84 & 17,4 \\
\hline $3601-4600 €$ & 44 & 9,1 \\
\hline $4601-5600 €$ & 30 & 6,2 \\
\hline 5601-6600€ & 14 & 2,9 \\
\hline $6601-7600 €$ & 5 & 1 \\
\hline $7601-8600 €$ & 1 & 0,2 \\
\hline $8601-9600 €$ & 4 & 0,8 \\
\hline $9600 €$ ve üstü & 6 & 1,2 \\
\hline Toplam & 483 & 100,0 \\
\hline
\end{tabular}


Tablo 5'de katılımcıların Iyaşpark Alışveriş Merkezi alışveriş alışkanlıklarına ait sorulara verdiği cevaplar yer almaktadır. Katılımcıların \%95,3'ü Iyaşpark alışveriş merkezinden alışveriş yaptığını belirtirken, \%4,7'si alışveriş yapmadığını belirtmiştir. Alışveriş yapmadığını belirten katılımcılar araştırmaya dâhil edilmemiştir. Araştırmaya Iyaşpark alışveriş merkezinden alışveriş yapan tüketiciler ile devam edilmiştir.

Bu doğrultuda katılımcıların \%98,8'i ayda bir defa Iyaşpark alışveriş merkezine gittiğini belirtmektedir. Katılımcıların \%55,3' ünün alışveriş yapmak için tercih ettiği gün hafta sonu olmaktadır. Katılımcıların \%35,2'si Iyaşpark alışveriş merkezine 14:01-16:00 arasında geldiklerini belirtmişlerdir. En düşük oranla katılımcıların \%2,7' si 10:00- 12:00 sabah saatlerini tercih edenler olmuştur.

Katılımcıların \%58,4'ü Iyaşpark alışveriş merkezinde 1-2 saat geçirdiklerini belirtmişlerdir. Katılımcıların Iyaşpark alışveriş merkezine en son gitme amaçları sorulmuştur. Katılımcıların \%72,3'ü alışveriş yapmak, \%39,5'i gezmek/vakit geçirmek, \%6,0'1 yemek yemek şeklinde cevap vermiştir.

Katılımcıların \%50,5'i Iyaşpark alışveriş merkezine ailesi ve akrabaları ile geldiğini belirtmiştir. Katılımcıların\%52,4' ünün Iyaşpark alışveriş merkezinden harcama miktarının 50250€ arası olduğunu belirtmiştir. Katılımcıların Iyaşpark alışveriş merkezi denildiğinde katılımcıların ilk aklına gelen kavramlar \%49,7 Kalabalık/Sıkıcı, \%40,0 Çeşitlilik, \%30,6 Çocuklar olarak tespit edilmiştir. Son olarak katılımcılara Iyaşpark AVM deneyimini tavsiye edip etmedikleri sorulmuştur. Katılımcıların \%79,1'i tavsiye ederim, \%20,9 'u tavsiye etmem şeklinde cevap vermiştir.

Tablo 5. Katılımcıların Iyaşpark alışveriş merkezi alışveriş alışkanlığı

\begin{tabular}{|l|l|l|}
\hline Iyaşpark alışveriş merkezinden alışveriş yaptınız mı? & Frekans & Yüzde\% \\
\hline Evet & 483 & 95,3 \\
Hayır & 24 & 4,7 \\
Toplam & $\mathbf{5 0 7}$ & $\mathbf{1 0 0 , 0}$ \\
\hline Iyaşpark alışveriş merkezine gitme sıklığınız nedir? & Frekans & Yüzde\% \\
\hline Haftada bir & 1 & 0,2 \\
İki haftada bir & 2 & 0,4 \\
Ayda bir & 476 & 98,8 \\
Daha az & 3 & 0,6 \\
Toplam & $\mathbf{4 8 3}$ & $\mathbf{1 0 0 , 0}$ \\
\hline Alışveriş yapmak için tercih edilen gün hangisidir? & Frekans & Yüzde\% \\
\hline Hafta içi & 216 & 44,7 \\
Hafta sonu & 267 & 55,3 \\
Toplam & $\mathbf{4 8 3}$ & $\mathbf{1 0 0 , 0}$ \\
\hline
\end{tabular}


Yeşilot, F. \& Dal, N. E.

\begin{tabular}{|c|c|c|}
\hline $\begin{array}{l}\text { Iyaşpark alışveriş merkezine genellikle günün hangi saatleri } \\
\text { geliyorsunuz? }\end{array}$ & Frekans & Yüzde\% \\
\hline 10:00-12:00 & 13 & 2,7 \\
\hline 12:01-14:00 & 28 & 5,8 \\
\hline 14:01-16:00 & 170 & 35,2 \\
\hline 16:01-18:00 & 53 & 11,0 \\
\hline 18:01-20:00 & 125 & 25,9 \\
\hline 20:01-22:00 & 94 & 19,5 \\
\hline Toplam & 483 & 100,0 \\
\hline Iyaşpark alışveriş merkezinde ne kadar zaman geçiriyorsunuz? & Frekans & Yüzde\% \\
\hline $30-1$ saat & 94 & 19,5 \\
\hline $1-2$ saat & 282 & 58,4 \\
\hline 3-4 saat & 100 & 20,7 \\
\hline $5-6$ saat & 5 & 1,0 \\
\hline 7 saatten fazla & 2 & 0,4 \\
\hline Toplam & 483 & 100,0 \\
\hline Iyaşpark alışveriş merkezine en son gitme amacınız nedir? & Frekans & Yüzde\% \\
\hline Alıșveriş yapmak & 349 & 72,3 \\
\hline Gezmek/vakit geçirmek & 191 & 39,5 \\
\hline Yemek yemek & 174 & 36,0 \\
\hline Arkadaşlarımla bir araya gelmek & 91 & 18,8 \\
\hline Vitrinlere bakmak & 46 & 9,5 \\
\hline Çocuğumu/çocuklarımı eğlendirmek & 59 & 12,2 \\
\hline Sinemaya gitmek & 124 & 25,7 \\
\hline Kültürel etkinlikleri/Organizasyonları izlemek & 14 & 2,9 \\
\hline Toplam & 1048 & 216,9 \\
\hline Iyaşpark alışveriş merkezine en çok kimlerle geliyorsunuz? & Frekans & Yüzde\% \\
\hline Tek başıma & 37 & 7,7 \\
\hline Ailem/Akrabalarım & 244 & 50,5 \\
\hline Arkadaşım/Arkadaşlarım & 202 & 41,8 \\
\hline Toplam & 483 & 100,0 \\
\hline $\begin{array}{l}\text { Iyaşpark alışveriş merkezinde yaklaşık olarak gerçekleştirdiğiniz toplam } \\
\text { harcama miktarınız nedir? }\end{array}$ & Frekans & Yüzde\% \\
\hline ( & 66 & 13,7 \\
\hline $50-250 €$ & 253 & 52,4 \\
\hline 251-450€ & 57 & 11,8 \\
\hline 451-650€ & 21 & 4,3 \\
\hline $651-850 €$ & 8 & 1,7 \\
\hline $851-1050$ モ & 14 & 2,9 \\
\hline 1051 € ve üstü & 64 & 13,3 \\
\hline Toplam & 483 & 100,0 \\
\hline Iyaşpark alışveriş merkezi denince ilk aklınıza gelenler nelerdir? & Frekans & Yüzde\% \\
\hline Çocuklar & 148 & 30,6 \\
\hline Sosyalleşme & 124 & 25,7 \\
\hline Çeşitlilik & 193 & 40,0 \\
\hline Renkli & 83 & 17,2 \\
\hline Çılgınlık & 16 & 3,3 \\
\hline Hesaplı & 81 & 16,8 \\
\hline Modern & 88 & 18,2 \\
\hline Kalabalık/sıkıcı & 240 & 49,7 \\
\hline Toplam & 973 & 201,5 \\
\hline Iyașpark alıșveriș merkezi deneyiminizi değerlendiriniz? & Frekans & Yüzde\% \\
\hline Tavsiye ederim & 382 & 79,1 \\
\hline Tavsiye etmem & 101 & 20,9 \\
\hline Toplam & 483 & 100,0 \\
\hline
\end{tabular}




\subsection{Normallik Testi}

İstatistiksel testler, "parametrik testler'” ve "parametrik olmayan testler" olmak üzere ikiye ayrılır. Normallik testi için Kolmogorow-Smirnov ve Shapiro -Wilk normallik testi uygulanmaktadır. Örneklem sayısının 30'dan fazla olması nedeniyle "Kolmogorov-Smirnov test" sonucu dikkate alınmıştır. Kolmogorow-Smirnov sonucuna göre $p<0,05$ olduğundan normallik varsayımı sağlanmamaktadır. $\mathrm{Bu}$ durumda parametrik olmayan analizlerin yapılabileceği anlaş1lır. (Durmuş vd., 2013: 66). Normallik testine ait bulgular Tablo 6'da verilmiştir.

Stratejik deneyimsel pazarlama boyutlarına yönelik değişkenlerin normal dağılıma uygunluk durumuna bakmak için ayrıca Tablo 7' de belirtilen çarpıklık ve basıklık değerlerine bakmak gerekmektedir. Bu değerler -2 ile +2 arasında ise normal dağılıma uygun olduğu anlaşılmaktadır. Çarpıklık ve basıklık değerlerine bakıldığında bu değerlerin -2 ve +2 aralığında olmadığı ve parametrik olmayan analizlerin yapılabileceği anlaşılmaktadır (Durmuş vd., 2013: $67)$.

Tablo 6. Normallik testi

\begin{tabular}{|c|c|c|c|c|c|c|}
\hline & \multicolumn{3}{|c|}{$\begin{array}{l}\text { Kolmogorov- } \\
\text { Smirnov }\end{array}$} & \multicolumn{3}{|c|}{ Shapiro-Wilk } \\
\hline & Statistic & df & Sig. & Statistic & df & Sig. \\
\hline $\begin{array}{l}\text { Iyaşpark alışveriş merkezinde rahat ve huzurlu bir ortam } \\
\text { vardır. }\end{array}$ &, 211 & 482 &, 000 & ,903 & 482 & ,000 \\
\hline $\begin{array}{l}\text { Iyaşpark alışveriş merkezinin dekorasyonu görsel olarak iyidir } \\
\text { ve etkileyicidir }\end{array}$ &, 187 & 482 &, 000 & ,912 & 482 & ,000 \\
\hline $\begin{array}{l}\text { Iyaşpark alışveriş merkezinin duvar ve zemin renkleri } \\
\text { tamamlayıcı ve eşgüdümlüdür }\end{array}$ & ,205 & 482 & , 000 & ,911 & 482 & ,000 \\
\hline Iyaşpark alışveriş merkezinde güzel ve etkileyici koku vardır &, 175 & 482 &, 000 &, 883 & 482 & ,000 \\
\hline Iyaşpark alışveriş merkezinin temizliği idealdir. &, 212 & 482 &, 000 & ,903 & 482 & ,000 \\
\hline $\begin{array}{l}\text { Iyaşpark alışveriş merkezinin aydınlatma, sıcaklık, mimari ve } \\
\text { çalışanların ilgisi benim duyguma uygundur }\end{array}$ &, 183 & 482 &, 000 & ,913 & 482 & ,000 \\
\hline $\begin{array}{l}\text { Iyaşpark alışveriş merkezinde kendimi rahatlamış ve mutlu } \\
\text { hissederim. }\end{array}$ & ,204 & 482 & ,000 & ,908 & 482 & ,000 \\
\hline $\begin{array}{l}\text { Iyaşpark alışveriş merkezinde zaman geçirmek keyifli ve } \\
\text { eğlencelidir }\end{array}$ &, 184 & 482 & ,000 & ,914 & 482 &, 000 \\
\hline $\begin{array}{l}\text { Iyaşpark alışveriş merkezinde zaman geçirmek beni günlük } \\
\text { hayattaki sıkıntılardan uzaklaştırır. }\end{array}$ &, 160 & 482 & , 000 & 901 & 482 &, 000 \\
\hline $\begin{array}{l}\text { Iyaşpark alışveriş merkezinde alışveriş esnasında kendimi } \\
\text { neşeli hissederim }\end{array}$ &, 170 & 482 &, 000 & ,916 & 482 & ,000 \\
\hline $\begin{array}{l}\text { Iyaşpark alışveriş merkezinde sunulan hizmet özenli olup } \\
\text { personel ilgilidir. }\end{array}$ &, 184 & 482 & ,000 & ,916 & 482 & ,000 \\
\hline $\begin{array}{l}\text { Iyaşpark alışveriş merkezi sosyalleşebileceğim ve vakit } \\
\text { geçirebileceğim bir mekândır. }\end{array}$ & ,179 & 482 & ,000 & ,910 & 482 & ,000 \\
\hline $\begin{array}{l}\text { Iyaşpark alışveriş merkezine gitmeyi seviyorum ve bundan } \\
\text { keyif alıyorum. }\end{array}$ & ,167 & 482 & ,000 & ,914 & 482 & ,000 \\
\hline
\end{tabular}


Yeşilot, F. \& Dal, N. E.

\begin{tabular}{|c|c|c|c|c|c|c|}
\hline $\begin{array}{lccc}\begin{array}{l}\text { Iyaşpark alışveriş } \\
\text { çevremle paylaşırım. }\end{array} & & \text { yaşadığım } & \text { deneyimleri } \\
\end{array}$ & 163, & 482 &, 000 & ,905 & 482 &, 000 \\
\hline $\begin{array}{l}\text { Iyaşpark alışveriş merkezinde yaşadığım deneyimler hayat } \\
\text { tarzımda değişiklik yapma isteğimi artırdı. }\end{array}$ & ,222 & 482 &, 000 & ,844 & 482 &, 000 \\
\hline $\begin{array}{l}\text { Iyaşpark alışveriş merkezi dikkat çekici ve değişik aktiviteler } \\
\text { düzenler }\end{array}$ &, 187 & 482 & ,000 &, 888 & 482 & ,000 \\
\hline Iyaşpark alışveriş merkezinin hizmet kalitesini beğenirim. &, 198 & 482 &, 000 & ,913 & 482 &, 000 \\
\hline $\begin{array}{l}\text { Iyaşpark alışveriş merkezine gitmeyi zaman kaybı olarak } \\
\text { düşünmüyorum }\end{array}$ &, 169 & 482 &, 000 & ,910 & 482 &, 000 \\
\hline Iyaşpark alışveriş merkezi yaşam kalitemi yükseltir. &, 165 & 482 &, 000 & ,896 & 482 & 000 \\
\hline $\begin{array}{l}\text { Iyaşpark alışveriş merkezinde istediğim mağazayı rahatça } \\
\text { bulurum. }\end{array}$ &, 185 & 482 &, 000 &, 890 & 482 &, 000 \\
\hline $\begin{array}{l}\text { Iyaşpark alışveriş merkezi sosyal çevremin gelişimine } \\
\text { yardımci olur. }\end{array}$ &, 184 & 482 &, 000 & ,875 & 482 & ,000 \\
\hline $\begin{array}{l}\text { Iyaşpark alışveriş merkezi satı̧ görevlileri ile rahatça iletişim } \\
\text { kurabilirim. }\end{array}$ & ,191 & 482 & ,000 & ,901 & 482 & ,000 \\
\hline $\begin{array}{l}\text { Iyaşpark alışveriş merkezinden yaşadığım deneyim aile ve } \\
\text { arkadaşlarıma yakınlaştırır. }\end{array}$ &, 174 & 482 & ,000 & ,889 & 482 & ,000 \\
\hline $\begin{array}{l}\text { Iyaşpark alışveriş merkezi hakkında basında çıkan haberleri } \\
\text { takip ederim. }\end{array}$ &, 262 & 482 & ,000 & ,817 & 482 & ,000 \\
\hline $\begin{array}{lllll}\begin{array}{l}\text { lyaşpark alışveriş merkezinde } \\
\text { davranışları beni rahatsız etmez. }\end{array} & \text { diğer } & \text { müşterilerin } \\
\end{array}$ & ,169 & 482 & ,000 & 910 & 482 & 000 \\
\hline
\end{tabular}

Iyaşpark alışveriş merkezi ile ilgili katılımcıların deneyimlerinin araştırıldığ sorulan ifadelere katılım derecesinin ortalama ve standart sapma değerleri Tablo 7'de görülmektedir. Katılımcıların ifadelere 5 'li likert ölçeğine göre (1- Kesinlikle katılmıyorum, 2Katılmiyorum, 3- Ne kat1liyorum ne kat1lmiyorum, 4- Katıliyorum ve 5- Kesinlikle katılıyorum) katılım düzeylerini belirtmeleri istenmiştir. Tablo 7'deki ortalamalar incelendiğinde katılımcıların "Iyaşpark AVM deneyimi” hakkında yer alan sorulara daha çok "Katılmıyorum" ve "Ne katıllyorum ne katılmıyorum" yanıtını verdiği söylenebilir. 
Tablo 7. Ortalama, standart sapma, çarpıklık ve basıklık değerleri

\begin{tabular}{|c|c|c|c|c|}
\hline & Ortalama & $\begin{array}{l}\text { Std. } \\
\text { Sapma }\end{array}$ & Çarpıklık & Basıklık \\
\hline Iyaşpark alışveriş merkezinde rahat ve huzurlu bir ortam vardır. & 3,13 & 1,120 &,- 303 &,- 407 \\
\hline $\begin{array}{l}\text { Iyaşpark alışveriş merkezinin dekorasyonu görsel olarak iyidir ve } \\
\text { etkileyicidir. }\end{array}$ & 2,76 & 1,098 &, 143 &,,- 560 \\
\hline $\begin{array}{l}\text { Iyaşpark alışveriş merkezinin duvar ve zemin renkleri tamamlayıcı ve } \\
\text { eşgüdümlüdür. }\end{array}$ & 2,84 & 1,081 &,- 030 &,- 596 \\
\hline Iyaşpark alışveriş merkezinde güzel ve etkileyici koku vardır. & 2,37 & 1,129 &, 386 &,- 669 \\
\hline Iyaşpark alışveriş merkezinin temizliği idealdir. & 3,28 & 1,091 &,- 381 &,- 487 \\
\hline $\begin{array}{l}\text { Iyaşpark alışveriş merkezinin aydınlatma, sıcaklık, mimari ve çalışanların } \\
\text { ilgisi benim duyguma uygundur. }\end{array}$ & 3,06 & 1,147 &,- 155 &,- 808 \\
\hline Iyaşpark alışveriş merkezinde kendimi rahatlamış ve mutlu hissederim. & 2,81 & 1,141 &, 072 &,- 606 \\
\hline Iyaşpark alışveriş merkezinde zaman geçirmek keyifli ve eğlencelidir. & 2,97 & 1,172 &,- 029 &,- 727 \\
\hline $\begin{array}{l}\text { Iyaşpark alışveriş merkezinde zaman geçirmek beni günlük hayattaki } \\
\text { sıkıntılardan uzaklaştırır. }\end{array}$ & 2,63 & 1,231 &, 243 &,- 898 \\
\hline $\begin{array}{l}\text { Iyaşpark alışveriş merkezinde alışveriş esnasında kendimi neşeli } \\
\text { hissederim. }\end{array}$ & 2,92 & 1,161 &,- 001 &,- 788 \\
\hline $\begin{array}{l}\text { Iyaşpark alışveriş merkezinde sunulan hizmet özenli olup personel } \\
\text { ilgilidir. }\end{array}$ & 3,05 & 1,107 &,- 104 &,- 623 \\
\hline $\begin{array}{l}\text { Iyaşpark alışveriş merkezi sosyalleşebileceğim ve vakit geçirebileceğim } \\
\text { bir mekandır }\end{array}$ & 2,86 & 1,208 &,- 007 &,- 879 \\
\hline Iyaşpark alışveriş merkezine gitmeyi seviyorum ve bundan keyif alıyorum. & 2,93 & 1,205 &, 028 &,- 830 \\
\hline Iyaşpark alışveriş merkezinde yaşadığım deneyimleri çevremle paylaşırım. & 2,90 & 1,284 &,- 012 & $-1,024$ \\
\hline $\begin{array}{l}\text { Iyaşpark alışveriş merkezinde yaşadığım deneyimler hayat tarzımda } \\
\text { değişiklik yapma isteğimi artırdı. }\end{array}$ & 2,19 & 1,203 & ,734 &,- 418 \\
\hline Iyaşpark alışveriş merkezi dikkat çekici ve değişik aktiviteler düzenler. & 2,49 & 1,228 &, 449 &,- 730 \\
\hline Iyaşpark alışveriş merkezinin hizmet kalitesini beğenirim. & 2,94 & 1,096 &,- 089 &,- 611 \\
\hline Iyaşpark alışveriş merkezine gitmeyi zaman kaybı olarak düşünmüyorum. & 3,16 & 1,223 &,- 194 &,- 821 \\
\hline Iyaşpark alışveriş merkezi yaşam kalitemi yükseltir. & 2,56 & 1,209 &, 272 &,- 846 \\
\hline Iyaşpark alışveriș merkezinde istediğim mağazayı rahatça bulurum. & 3,28 & 1,331 &,- 333 &,- 998 \\
\hline Iyaşpark alışveriş merkezi sosyal çevremin gelişimine yardımcı olur. & 2,44 & 1,273 &, 450 &,- 905 \\
\hline Iyaşpark alışveriş merkezi satış görevlileri ile rahatça iletişim kurabilirim. & 3,41 & 1,184 &,- 373 &,- 686 \\
\hline $\begin{array}{l}\text { Iyaşpark alışveriş merkezinden yaşadığım deneyim aile ve arkadaşlarıma } \\
\text { yakınlaştırır. }\end{array}$ & 2,57 & 1,281 &, 356 &,- 932 \\
\hline Iyaşpark alışveriş merkezi hakkında basında çıkan haberleri takip ederim. & 2,17 & 1,285 &, 761 &,- 617 \\
\hline $\begin{array}{l}\text { Iyaşpark alışveriş merkezinde ki diğer müşterilerin davranışları beni } \\
\text { rahatsız etmez. }\end{array}$ & 2,98 & 1,248 &,- 040 &,- 913 \\
\hline
\end{tabular}




\subsection{Mann Whitney U Testi}

Mann Whitney U testi iki bağımsız ortalama arasındaki farkın anlamlı olup olmadığını test eden en yaygın kullanıma sahip parametrik olmayan analiz yöntemidir. Mann- Whitney U testi verinin normal dağılıma uymadığı durumlarda kullanılmaktadır (Gürbüz ve Şahin, 2015: 240).

\section{Hipotezler:}

H0: Katılımcıların yaşadığı stratejik deneyimsel pazarlama boyutları ile Iyaşpark alışveriş merkezi deneyimi arasında istatistiksel olarak anlamlı bir farklılık yoktur.

H1: Katılımcıların yaşadığı stratejik deneyimsel pazarlama boyutları ile Iyaşpark alışveriş merkezi deneyimi arasında istatistiksel olarak anlamlı bir farklılık vardır.

Tablo 8. Katılımcıların yaşadığı stratejik deneyimsel pazarlama boyutlarının Iyaşpark alışveriş merkezi deneyim değişkenine göre Mann Whitney U Testi

\begin{tabular}{|l|c|c|c|c|}
\hline & $\begin{array}{c}\text { Iyaşpark alışveriş merkezi } \\
\text { deneyiminizi } \\
\text { değerlendiriniz. }\end{array}$ & $\mathrm{N}$ & $\begin{array}{c}\text { Sira } \\
\text { Ortalamaları }\end{array}$ & Sıra Toplamları \\
\hline & Tavsiye Ederim & 382 & 279,87 & 106911,00 \\
$\begin{array}{l}\text { Ölçek } \\
\text { ortalama }\end{array}$ & Tavsiye Etmem & 101 & 98,76 & 9975,00 \\
& Toplam & 483 & & \\
\hline
\end{tabular}

\begin{tabular}{|l|l|}
\hline & Ölçek Ortalamaları \\
\hline Mann-Whitney U & 4824,000 \\
Wilcoxon W & 9975,000 \\
Z & $-11,599$ \\
$\mathrm{P}$ &, 000 \\
\hline
\end{tabular}

Katılımcıların yaşadığı stratejik deneyimsel pazarlama boyutlarının Iyaşpark alışveriş merkezi deneyim değişkenine göre Mann Whitney U Testi Tablo 8' de gösterilmiştir. Tablo 8' de yer alan P değeri istatistiksel anlamlılık hesaplamalarında sınır değer kabul edilen 0,05 ' ten küçük olması gözlemlenen değerler arasında anlamlı bir farklılık olduğunu göstermektedir (Gürbüz ve Şahin, 2015: 243).

P değeri 0,000<0,05 olduğu için 0.05 güven düzeyinde Ho red edilir ve H1 kabul edilir. Stratejik Deneyimsel Pazarlama Boyutları ile Iyaşpark Alışveriş Merkezi Deneyimini tavsiye 
etme ya da tavsiye etmeme arasında istatistiksel olarak anlamlı bir farklılık vardır. Katılımcılardan Iyaşpark Alışveriş Merkezi Deneyimini değerlendirmeleri istendiğinde 483 katılımcının 382'si tavsiye ederim yanıtını vermiş̧tir. 101 katılımcı ise Iyaşpark alışveriş merkezinde yaşadığı deneyimi tavsiye etmemektedir. Tablo 8 'de görüldüğü üzere tavsiye ederim yanıtını veren katılımcıların sıra ortalaması 279,87, tavsiye etmem yanıtını veren katılımcıların sıra ortalaması 98,76'dır. Buna göre stratejik deneyimsel pazarlama boyutları ile Iyaşpark alışveriş merkezini tavsiye eden katılımcılar ile tavsiye etmeyen katılımcılar arasında istatistiksel olarak anlamlı fark olduğu görülmektedir.

\subsection{Kruskal Wallis Testi}

Kruskal Wallis testi, normal dağılım göstermeyen veriye sahip birbirinden bağımsız örneklemin bağımlı bir değişkene ait ölçümlerinin karşılaştırılmasında ve ikiden fazla kategoriyi karşılaştırmak için kullanılmaktadır (Gürbüz ve Şahin, 2015: 238).

Stratejik deneyimsel pazarlama boyutlarının gelir seviyesine göre bir farkl1lık gösterip göstermediğini ölçmeye yönelik yapılan Kruskal Wallis testi Tablo 9'da gösterilmiştir. Kruskal Wallis test istatistiğinde, ikiden fazla gruplu değişkenlerin karşılaştırılması için grupların aldığı değerler sıralı hale dönüştürülmekte ve P değeri 0,05 değerinden küçük olduğunda, gruplar arasındaki sıralamanın birbirinden farklılık gösterdiği söylenmektedir (Durmuş vd., 2011: 195).

Tablo 9. Katılımcıların stratejik deneyimsel pazarlama boyutuna ilişkin gelir değişkenine göre Kruskal Wallis Testi

\begin{tabular}{|l|l|l|}
\hline Stratejik Deneyimsel Pazarlama Boyutları & N & P \\
\hline Duyusal Deneyim & 483 &, 069 \\
\hline Duygusal Deneyim & $\mathbf{4 8 3}$ & $\mathbf{, 0 0 0}$ \\
\hline Davranışsal Deneyim & $\mathbf{4 8 3}$ & $\mathbf{, 0 0 6}$ \\
\hline Düşünsel Deneyim & $\mathbf{4 8 3}$ & $\mathbf{, 0 0 3}$ \\
\hline İlişkisel Deneyim & 483 &, 101 \\
\hline
\end{tabular}

Katılımcıların duyusal deneyim boyutuna verdiği yanıtlar sonucunda elde edilen $\mathrm{P}$ değeri 0,05 'ten büyük olduğu için katılımcıların gelirine göre istatistiksel olarak anlamlı bir farkl11ık göstermediği görülmektedir. İlişkisel deneyim boyutunun P değeri 0,05 ' ten büyük olduğu için katılımcıların gelirine göre istatistiksel olarak anlamlı bir farklılık göstermediği tespit edilmiştir.

Katılımcıların stratejik deneyimsel pazarlama boyutlarına ilişskin gelir değişkenine göre duygusal, davranışsal ve düşünsel deneyim boyutlarında P değeri 0,05 'ten küçük olduğu için 
istatistiksel olarak anlamlı farklılık olduğu görülmektedir. Tablo 10, Tablo 11, Tablo 12'de istatistiksel olarak anlamlı farklılık olan boyutlara yer verilmiştir.

Tablo 10. Katılımcıların duygusal deneyim boyutuna verdikleri cevapların gelir değişkenine göre Kruskal Wallis Testi Sonuçları

\begin{tabular}{|c|c|c|c|c|c|}
\hline Gelir & $\mathbf{N}$ & Sira Ortalamaları & Ki Kare & Df & $\mathbf{P}$ \\
\hline 1600 tl ve altı & 210 & 272,51 & \multirow{10}{*}{31,215} & \multirow{10}{*}{9} & \multirow{10}{*}{,000 } \\
\hline $1601-2600$ & 85 & 232,46 & & & \\
\hline 2601-3600 & 84 & 243,81 & & & \\
\hline $3601-4600$ & 44 & 196,90 & & & \\
\hline 4601-5600 & 30 & 196,10 & & & \\
\hline $5601-6600$ & 14 & 200,21 & & & \\
\hline 6601-7600 & 5 & 174,20 & & & \\
\hline 7601-8600 & 1 & 155,00 & & & \\
\hline $8601-9600$ & 4 & 131,80 & & & \\
\hline 9601 ve üstü & 6 & 86,50 & & & \\
\hline
\end{tabular}

\section{Hipotezler:}

H0: Duygusal deneyim ile gelir değişkeni arasında istatistiksel olarak anlamlı bir farkl1l1k yoktur.

H1: Duygusal deneyim ile gelir değişkeni arasında istatistiksel olarak anlamlı bir farkl11ık vardır.

Katılımcıların duygusal deneyim boyutuna verdikleri cevapların gelir değişkenine göre istatistiksel olarak anlamlı bir farklılık olduğu görülmektedir. $\mathrm{P}<0,05$ olduğundan $\mathrm{H} 0$ red edilir. H1 kabul edilir. Tablo 10' da gösterilen sıra ortalamaları dikkate alındığında 1600 TL ve altı gelire sahip katılımcıların duygusal deneyim boyutuna daha çok katıldıkları söylenebilir.

Tablo 11. Katılımcıların davranışsal deneyim boyutuna verdikleri cevapların gelir değişkenine göre Kruskal Wallis Testi Sonuçları

\begin{tabular}{|c|c|c|c|c|c|}
\hline Gelir & $\mathbf{N}$ & Sira Ortalamaları & Ki Kare & Df & $\mathbf{P}$ \\
\hline 1600 tl ve altı & 210 & 266,47 & \multirow{10}{*}{23,174} & \multirow{10}{*}{9} & \multirow{10}{*}{,006 } \\
\hline 1601-2600 & 85 & 223,16 & & & \\
\hline 2601-3600 & 84 & 247,80 & & & \\
\hline $3601-4600$ & 44 & 200,28 & & & \\
\hline $4601-5600$ & 30 & 233,30 & & & \\
\hline $5601-6600$ & 14 & 206,11 & & & \\
\hline 6601-7600 & 5 & 235,90 & & & \\
\hline 7601-8600 & 1 & 224,00 & & & \\
\hline $8601-9600$ & 4 & 81,25 & & & \\
\hline 9601 ve üstü & 6 & 119,58 & & & \\
\hline
\end{tabular}




\section{Hipotezler:}

H0: Davranışsal deneyim ile gelir değişkeni arasında istatistiksel olarak anlamlı bir farklıl1k yoktur.

H1: Davranışsal deneyim ile gelir değişkeni arasında istatistiksel olarak anlamlı bir farklılık vardır.

Katılımcıların davranışsal deneyim boyutuna verdikleri cevapların gelir değişkenine göre istatistiksel olarak anlamlı bir farklılık olduğu görülmektedir. $\mathrm{P}<0,05$ olduğundan $\mathrm{H} 0$ red edilir. H1 kabul edilir. Tablo 11' de gösterilen sıra ortalamaları dikkate alındığında 1600 TL ve altı gelire sahip katılımcıların davranışsal deneyim boyutuna daha çok katıldıkları söylenebilir.

Tablo 12. Katılımcıların düşünsel deneyim boyutuna verdikleri cevapların gelir değişkenine göre Kruskal Wallis Testi sonuçları

\begin{tabular}{|c|c|c|c|c|c|}
\hline Gelir & $\mathbf{N}$ & Sira Ortalamaları & Ki Kare & Df & $\mathbf{P}$ \\
\hline 1600 tl ve altı & 210 & 267,04 & \multirow{10}{*}{25,353} & \multirow{10}{*}{9} & \multirow{10}{*}{,003 } \\
\hline $1601-2600$ & 85 & 220,93 & & & \\
\hline 2601-3600 & 84 & 248,49 & & & \\
\hline $3601-4600$ & 44 & 214,20 & & & \\
\hline 4601-5600 & 30 & 240,33 & & & \\
\hline $5601-6600$ & 14 & 186,43 & & & \\
\hline 6601-7600 & 5 & 125,70 & & & \\
\hline 7601-8600 & 1 & 146,00 & & & \\
\hline $8601-9600$ & 4 & 117,00 & & & \\
\hline 9601 ve üstü & 6 & 111,42 & & & \\
\hline
\end{tabular}

\section{Hipotezler:}

H0: Düşünsel deneyim ile gelir değişkeni arasında istatistiksel olarak anlamlı bir farkl11ı yoktur.

H1: Düşünsel deneyim ile gelir değişkeni arasında istatistiksel olarak anlamlı bir farkl11ık vardır.

Katılımcıların düşünsel deneyim boyutuna verdikleri cevapların gelir değişkenine göre istatistiksel olarak anlamlı bir farklılık $(\mathrm{p}<0,05)$ gösterdiği görülmektedir. $\mathrm{P}<0,05$ olduğundan H0 red edilir. H1 kabul edilir. Tablo 12' de gösterilen sıra ortalamaları dikkate alındığında 1600 tl ve altı gelire sahip katılımcıların düşünsel deneyim boyutuna daha çok katıldıkları söylenebilir. 


\subsection{Mann-Whitney U Testi}

Mann-Whitney U testi iki bağımsız ortalama arasındaki farkın anlamlı olup olmadığını test eden en yaygın kullanıma sahip parametrik olmayan analiz yöntemidir. Mann-Whitney U testi verinin normal dağılıma uymadığı durumlarda kullanılmaktadır (Gürbüz ve Şahin, 2015: 240).

Tablo 13. Duyusal deneyim boyutunun cinsiyet değişkenine göre Mann-Whitney U Testi

\begin{tabular}{|c|c|c|c|c|c|}
\hline Cinsiyet & N & Sira Ortalamaları & Siranın Toplamı & Mann Whitney U & P \\
\cline { 1 - 4 } Kadın & 355 & 249,68 & 88638,00 & \multirow{2}{*}{19992,000} & \multirow{2}{*}{043} \\
\cline { 1 - 4 } Erkek & 128 & 220,69 & 28248,00 & & \\
\hline
\end{tabular}

\section{Hipotezler:}

H0: Duyusal deneyim ile cinsiyet arasında istatistiksel olarak anlamlı bir farklılık yoktur.

H1: Duyusal deneyim ile cinsiyet arasında istatistiksel olarak anlamlı bir farklılık vardir.

Duyusal deneyim boyutunun cinsiyet değişkenine göre Mann-Whitney U Testi Tablo 13'de gösterilmiştir. Tablo 13'de yer alan P değeri istatistiksel anlamlılık hesaplamalarında sınır değer kabul edilen 0,05 'ten küçük olması gözlemlenen değerler arasında anlamlı bir fark olduğunu göstermektedir (Gürbüz ve Şahin, 2015: 243).

P değeri $0,043<0.05$ olduğu için 0.05 güven düzeyinde H0 red edilir. H1 kabul edilir. Duyusal deneyim ile cinsiyet arasında istatistiksel olarak anlamlı bir fark vardır. Sıra ortalamaları dikkate alındığında kadın katılımcıların sıra ortalamalarının yüksek olduğu söylenebilir.

Tablo 14. Duygusal deneyim boyutunun cinsiyet değişkenine göre Mann-Whitney U sonuçları

\begin{tabular}{|c|c|c|c|c|c|}
\hline Cinsiyet & N & Sira Ortalamaları & Siranın Toplamı & Mann Whitney U & P \\
\cline { 1 - 4 } Kadın & 355 & 251,49 & 89280,00 & \multirow{2}{*}{19350,000} & \multirow{2}{*}{, 013} \\
\cline { 1 - 4 } Erkek & 128 & 215,67 & 27606,00 & & \\
\hline
\end{tabular}




\section{Hipotezler:}

H0: Duygusal deneyim ile cinsiyet arasında istatistiksel olarak anlamlı bir farklılık yoktur.

H1: Duygusal deneyim ile cinsiyet arasında istatistiksel olarak anlamlı bir farklılık vardir.

P değeri 0,013<0,05 olduğu için 0.05 güven düzeyinde Ho Red edilir. H1 kabul edilir. Duygusal deneyim ile cinsiyet arasında istatistiksel olarak anlamlı bir fark vardır. Tablo 14'de görüldüğü üzere kadın katılımcıların sıra ortalaması 251,49 erkek katılımcıların sıra ortalaması 215, 67'dir.

Tablo 15. Davranışsal deneyim boyutunun cinsiyet değişkenine göre MannWhitney U sonuçları

\begin{tabular}{|c|c|c|c|c|c|}
\hline Cinsiyet & N & Sıra Ortalamaları & Sıranın Toplamı & Mann Whitney U & P \\
\hline Kadın & 355 & 251,59 & 89313,50 & 193316,500 & \multirow{2}{*}{012} \\
\hline Erkek & 128 & 215,41 & 27572,50 & & \\
\hline
\end{tabular}

\section{Hipotezler:}

H0: Davranışsal deneyim ile cinsiyet arasında istatistiksel olarak anlamlı bir farklılık yoktur.

H1: Davranışsal deneyim ile cinsiyet arasında istatistiksel olarak anlamlı bir farklılık vardir.

Tablo 15' de görüldüğg̈ gibi $\mathrm{P}$ değeri $0,012<0,05$ olduğu için 0.05 güven düzeyinde Ho Red edilir. H1 kabul edilir. Davranışsal deneyim ile cinsiyet arasında istatistiksel olarak anlamlı bir farklılık vardır. Tablo 15'de görüldüğü üzere kadınların sıra ortalaması 251,49 erkeklerin s1ra ortalamas 1215,41 'dir.

Tablo 16. Düşünsel deneyim boyutunun cinsiyet değişkenine göre Mann-Whitney U sonuçları

\begin{tabular}{|c|c|c|c|c|c|}
\hline Cinsiyet & N & Sıra Ortalamaları & Sıranın Toplamı & Mann-Whitney U & P \\
\cline { 1 - 4 } Kadın & 355 & 253,51 & 89995,00 & \multirow{2}{*}{18635,000} & \multirow{2}{*}{, 002} \\
\cline { 1 - 3 } Erkek & 128 & 210,09 & 26891,00 & & \\
\hline
\end{tabular}




\section{Hipotezler:}

H0: Düşünsel deneyim ile cinsiyet arasında istatistiksel olarak anlamlı bir farklılık yoktur.

H1: Düşünsel deneyim ile cinsiyet arasında istatistiksel olarak anlamlı bir farklılık vardir.

P değeri $0,002<0,05$ olduğu için 0.05 güven düzeyinde Ho red edilir. H1 kabul edilir. Düşünsel deneyim ile cinsiyet arasında istatistiksel olarak anlamlı bir fark vardır. Sıra ortalamaları dikkate alındığında kadın katılımcıların düşünsel deneyimlere daha çok katıldığı söylenebilir.

Tablo 17. İlişkisel deneyim boyutunun cinsiyet değişkenine göre Mann-Whitney U sonuçları

\begin{tabular}{|c|c|c|c|c|c|}
\hline Cinsiyet & $\mathbf{N}$ & Sıra Ortalamaları & Sıranın Toplamı & Mann-Whitney U & P \\
\cline { 1 - 3 } Kadın & 355 & 247,77 & 87957,50 & \multirow{2}{*}{20672,500} & \multirow{2}{*}{, 129} \\
\cline { 1 - 3 } Erkek & 128 & 226,00 & 28928,50 & & \\
\hline
\end{tabular}

\section{Hipotezler:}

H0: İlişkisel deneyim ile cinsiyet arasında istatistiksel olarak anlamlı bir farklılık yoktur.

H1: İlişkisel deneyim ile cinsiyet arasında istatistiksel olarak anlamlı bir farklılık vardır.

P değeri 0,129>0,05 olduğu için 0.05 güven düzeyinde Ho kabul edilir. H1 red edilir. İlişkisel deneyim ile cinsiyet arasında istatistiksel olarak anlamlı bir fark yoktur. Tablo 17'de görüldüğü üzere kadınların sıra ortalaması 247,77 erkeklerin sıra ortalaması ise 226,00'dır.

\subsection{Katılımcıların Medeni Durum Değişkenine Göre Mann-Whitney U Testi}

Katılımcıların duyusal, davranışsal, düşünsel ve ilişkisel deneyim boyutuna verdiği yanıtlar sonucunda elde edilen $P$ değeri 0,05 'ten büyük olduğu için katılımcıların medeni durumlarına göre istatistiksel olarak anlamlı bir farklılık göstermediği tespit edilmiştir.

Katılımcıların stratejik deneyimsel pazarlama boyutlarına ilişkin medeni durum değişkenine göre duygusal deneyim boyutunda istatistiksel olarak anlamlı farklılık olduğu 
$(p<0,05)$ görülmektedir. Katılımcıların medeni durum değişkenine göre Mann-Whitney U Testi sonuçlarına Tablo 18 ve Tablo 19'da yer verilmiştir.

Tablo 18. Katılımcıların stratejik deneyimsel pazarlama boyutuna ilişkin medeni durum değişkenine göre Mann-Whitney U Testi

\begin{tabular}{|l|l|l|}
\hline Stratejik Deneyimsel Pazarlama Boyutları & N & P \\
\hline Duyusal Deneyim & 483 &, 386 \\
\hline Duygusal Deneyim & $\mathbf{4 8 3}$ & $\mathbf{, 0 1 2}$ \\
\hline Davranışsal Deneyim & 483 &, 881 \\
\hline Düşünsel Deneyim & 483 &, 077 \\
\hline İlişkisel Deneyim & 483 &, 722 \\
\hline
\end{tabular}

Tablo 19. Duygusal deneyim boyutunun medeni durum değişkenine göre MannWhitney U Testi Sonuçları

\begin{tabular}{|c|c|c|c|c|c|}
\hline Medeni Durum & N & Sira Ortalamaları & Siranın Toplamı & Mann-Whitney U & P \\
\cline { 1 - 4 } Evli & 243 & 228,31 & 55480,50 & \multirow{2}{*}{25834,500} & \multirow{2}{*}{, 012} \\
\hline Bekar & 240 & 255,86 & 61405,50 & & \\
\hline
\end{tabular}

\section{Hipotezler:}

H0: Duygusal deneyim ile medeni durum arasında istatistiksel olarak anlamlı bir farkl111k yoktur.

H1: Duygusal deneyim ile medeni durum arasında istatistiksel olarak anlamlı bir farkl111k vardır.

P değeri $0,012<0,05$ olduğu için 0.05 güven düzeyinde Ho red edilir. H1 kabul edilir. Katılımcıların duygusal deneyimleri ile medeni durum arasında istatistiksel olarak anlamlı bir fark tespit edilmiştir. Tablo 19'da görüldüğü üzere evlilerin sıra ortalaması 228,31 bekarların sira ortalamas 1255,86 'dir.

\section{SONUÇ VE ÖNERILER}

Deneyimsel pazarlama, müşteri ürün ve hizmeti satın almadan müşteriye satın alacağı ürün ve hizmetin sağlayacağı faydayı müşteriye yaşatmaya odaklanan bir pazarlama anlayışıdır. İşletmeler müşteriyi yakından tanıma, müşterinin istek ve ihtiyaçlarını sunma, müşteri memnuniyetini sağlama başarılı bir pazarlama stratejisi ile hizmet sunma çabası içine girmektedirler. 
Günümüzde müşteri eğlenmek, gezmek, keyifli vakit geçirmek, alışveriş yapmak için deneyim sunan mekânlar olan AVM'leri tercih etmektedir. Stratejik deneyimsel pazarlama boyutları duyusal, duygusal, düşünsel, davranışsal ve ilişkisel deneyim boyutları müşterinin beş duyusuna hitap ederek hafizalarında kalıcı izler bırakmayı istemektedir. Bu boyutlardaki bağlantıları sağlama da beş duyu büyük önem taşımaktadır. Müşterinin duygu ve düşüncelerine, ihtiyaçlarına hitap eden deneyimsel boyutlar müşterilerine deneyim sunmayı amaçlamaktadır. Müşteri duyduğu sesi, tattığı tadı, hissettiği bir şeyi, gördüğü görüntüyü ve kokladığı kokuyu ürün ve hizmet ile bağdaştırırsa hafızasında güçlü bir konumda yer edinmektedir.

Müşteriye pozitif duygular yaşatan hislerine hitap eden pazarlama stratejileri geliştirerek müşteri deneyimine önem veren işletmeler rekabet avantajı sağlayarak tüketicilerine güçlü ve unutulmaz deneyimler yaşatmış olacaklardır. Günümüz müşteri profilinde meydana gelen değişim deneyimsel pazarlamanın önemini gittikçe artırmaktadır.

Çalışmada elde edilen verilerin analizi için; normal dağılım testi, güvenilirlik analizi, frekans analizi, Mann Whitney U testi, Kruskal Wallis testi kullanılmıştır. Normallik varsayımı sağlanmamaktadır. Cronbach's Alpha analizine göre ölçeğin güvenilirlik katsayısı 0.956 olduğu tespit edilmiştir. Elde edilen sonuç ölçeğin yüksek güvenilirliğe sahip olduğunu göstermektedir.

Frekans analizine göre elde edilen sonuçlar; araştırmaya katılan tüketicilerin demografik özellikleri incelendiğinde kadın katılımcının fazla olduğu görülmektedir. Katılımcıların medeni durumlarına bakıldığında ise evli katılımcıların çoğunluktadır. Katılımcıların yaş aralığı değerlendirildiğinde, 26-35 yaş aralığındaki katılımcı daha fazladır. Katılımcıların çoğunluğu öğrencilerden oluşmaktadır. Katılımcıların çoğunluğu lisans mezunu ve gelir düzeyleri de 1600 TL ve altındadır.

Katılımcıların AVM' ye gitme sıklığı sorulduğunda en yüksek verilen cevap ayda bir olmuştur. Katılımcılar alışveriş yapmak için hafta sonunu tercih ettiklerini belirtmişlerdir. AVM' ye gidilen saatlere katılımcıların büyük çoğunluğu 14:01-16:00 arasında geldiklerini belirtmişlerdir. En düşük oranla 10:00- 12:00 sabah saatlerini tercih edenler olmuştur. Sabah saatlerinin alışveriş için tercih edilmediği söylenebilir.

Katılımcıların çoğu AVM'de 1-2 saat geçirdiklerini belirtmişlerdir. AVM' ye en son gitme amaçlarının sırasıyla alışveriş yapmak, gezmek/vakit geçirmek, yemek yemek, sinemaya gitmek, arkadaşlarıyla bir araya gelmek, çocuğumu/çocuklarımı eğlendirmek, vitrinlere 
bakmak, şeklinde cevap verilmiştir. Katılımcıların AVM'ye gitme amaçları sorusuna verdikleri cevaplarda en düşük yüzde kültürel etkinlikleri/organizasyonları izlemek olmuştur. Ayrıca katılımcılar AVM' ye en çok aile/akrabalar ile geldiklerini belirtmişlerdir. Bunu arkadaşım/arkadaşlarım cevabı izlemektedir. Katılımcıların AVM' de gerçekleştirdikleri harcama miktarı ise en yüksek 50-250 TL arası, en düşük harcama miktarı ise 651-850 TL arası olarak tespit edilmiştir.

Katılımcıların Iyaşpark AVM denince ilk akıllarına gelen Kalabalık/Sıkıcı olduğu tespit edilmiştir. Daha sonra sırasıyla, çeşitlilik, çocuklar, sosyalleşme, modern, renkli, hesaplı olduğunu belirtmektedirler. Iyaşpark AVM denince katılımcıların düşük bir oranının ise aklına çılgınlık kavramı gelmektedir. Ayrıca Iyaşpark AVM müşterisi olan katılımcıların büyük çoğunluğu AVM deneyimlerini değerlendirdiklerinde Iyaşpark AVM'yi tavsiye ederim şeklinde yanıt vermiştir.

Mann-Whitney U testi ile katılımcıların yaşadı̆̆ stratejik deneyimsel pazarlama boyutları (duyusal, duygusal, düşünsel, davranışsal ve ilişkisel) ile Iyaşpark alışveriş merkezi deneyimini tavsiye etme ya da tavsiye etmeme arasında istatistiksel olarak anlamlı bir farklılık olup olmadığı araştırılmıştır. Buna göre elde edilen sonuçlar, stratejik deneyimsel pazarlama boyutları ile Iyaşpark Alışveriş Merkezi deneyimini tavsiye etme ya da tavsiye etmeme arasında istatistiksel olarak anlamlı bir farklılık tespit edilmiştir. Katılımcıların büyük çoğunluğu Iyaşpark alışveriş merkezinde yaşadığı deneyimi tavsiye etmektedir.

Araştırma problemi niteliğindeki sorular demografik bilgiler dikkate alınarak incelendiğinde genel olarak ifade edilmesi gereken önemli sonuçlar şunlardır; Kruskal- Wallis testi ile katılımcıların stratejik deneyimsel pazarlama boyutuna verdikleri cevapların gelir değişkenine göre istatistiksel olarak anlamlı bir farklılık gösterip göstermediği araştırılmıştır. Duygusal, düşünsel ve davranışsal deneyim boyutlarının gelir değişkeni bakımından istatistiksel olarak anlamlı bir farklılık olduğu tespit edilmiştir. Katılımcıların 1600 TL ve altı gelire sahip olanların duygusal, düşünsel ve davranışsal boyutlara daha çok katıldıkları söylenebilir.

Yapılan çalışmada duyusal ve ilişkisel deneyim boyutlarının tüketicilerin gelirine göre anlamlı bir farklılık göstermemektedir. Bu nedenle katılımcıların beş duyusuna hitap eden duyusal deneyim ve bir gruba ait olma duygusu geliştiren ilişkisel deneyim boyutlarının gelirin artıp azalmasından etkilenmediği söylenebilir. 
Katılımcıların yaşadıkları deneyim boyutları ile gelir değişkeni arasındaki farklılık incelendiğinde, duyusal ve ilişkisel deneyim boyutları tüketicinin gelirine göre anlamlı bir farklılık göstermediği görülmektedir. Duyusal ve ilişkisel deneyim boyutları gelirin artıp azalmasından etkilenmemektedir. Duygusal, düşünsel ve davranışsal deneyim boyutları ise gelirin artıp azalmasından etkilenmektedir.

Mann-Whitney $U$ testi ile tüketicilerin stratejik deneyimsel pazarlama boyutlarına ilişkin cinsiyet değişkenine göre istatistiksel olarak anlamlı bir farklılık olup olmadığ araştırılmıştır. Duyusal, duygusal, düşünsel ve davranışsal deneyim boyutlarının cinsiyet bakımından istatistiksel olarak anlamlı bir farklılık gösterdiği tespit edilmiştir. Ayrıca sıra ortalamaları dikkate alındığında deneyim boyutlarının kadın katılımcıların daha çok önem verdiği söylenebilir. İlişkisel deneyim boyutu ile cinsiyet arasında istatistiksel olarak anlamlı bir fark yoktur.

Katılımcıların yaşadıkları deneyim boyutları, cinsiyet değişkenine göre farklılık göstermektedir. Kadınlar, erkeklere göre deneyim pazarlamasının duyusal, duygusal, düşünsel ve davranışsal boyutlarına daha çok önem vermektedirler. Bir gruba ait olma duygusu geliştiren, ilişsiyi sürekli tutan, güvene dayalı ilişki içerisinde müşteri isteklerine cevap veren ilişkisel deneyim boyutu ile cinsiyet arasında istatistiksel olarak anlamlı farklılık bulunamamıştır.

Tunç (2017), çalışmasında Burger King ürünlerini iç dizayn ve sosyal fayda ölçeğine göre değerlendirmiş ve duyusal, duygusal, düşünsel, davranışsal ve ilişkisel deneyim boyutları ile cinsiyet arasında anlamlı bir fark olduğunu tespit etmiştir. Burger King işletmecileri cinsiyet özelliklerine göre sosyal fayda stratejileri yürütmektedir. Burger King işletmeleri kadın ve erkeklere ayrı hitap edebilmelidir. Yapılan çalışmada duyusal, duygusal, düşünsel ve davranışsal deneyim boyutlarının cinsiyet bakımından istatistiksel olarak anlamlı bir farklılık gösterdiği tespit edilmiştir. Sadece ilişkisel deneyim boyutu ile cinsiyet arasında istatistiksel olarak anlamlı farklılık bulunamamıştır.

Kara ve Çiçek (2015) ise çalışmasında tüketicilerin satın alma kararlarını etkileyen beş faktör tespit edilmiştir. Bu faktörler ile cinsiyet arasında anlamlı bir farklılığın olup olmadığı araştırılmıştır. Erkek veya kadın tüketiciler arasında anlamlı farklılık ortaya çıkmamış iken yapılan çalışmada duyusal, duygusal, düşünsel ve davranışsal deneyim boyutlarının cinsiyet bakımından istatistiksel olarak anlamlı bir farklılık gösterdiği tespit edilmiştir. Sadece ilişkisel deneyim boyutu ile cinsiyet arasında istatistiksel olarak anlamlı farklılık bulunamamıştır. 
Ercan (2018) ise çalışmasında katılımcıların hedonik tüketimin alt boyutlarına ait görüşlerde cinsiyet değişkeni arasında anlamlı fark bulmuştur. Erkek tüketicilerin maceracı alışveriş ve değer amaçlı alışveriş algıları kadın tüketicilere oranla daha düşük olduğunu tespit etmiştir. Kadınlar macera yaşamak, değer oluşturmak için alışveriş yapmaktadır. Benzer sonuçlara ulaşılan bu çalışmada kadınların deneyimsel pazarlama boyutlarına erkeklerden daha çok önem verdiği sonucuna ulaşılabilir.

Ayrıca yapılan çalışmada katılımcıların duygusal deneyimleri ile medeni durumları arasında istatistiksel olarak anlamlı bir fark olduğu tespit edilmiştir. Duyusal deneyim, davranışsal deneyim, düşünsel deneyim ve ilişkisel deneyim boyutları ile medeni durum arasında ise istatistiksel olarak anlamlı bir farklılık bulunmamaktadır. Evli ve bekâr katılımcılar arasında tüketicinin duygu ve hislerine yönelen duygusal deneyim boyutunda ise istatistiksel olarak anlamlı farklılık tespit edilmiştir.

Araştırma Isparta ilinde bulunan Iyaşpark alışveriş merkezinden alışveriş yapan katılımcılara yapıldı̆̆ı için genellenebilir nitelikte değildir. Sonuçların daha genellenebilir olması açısından farklı bölgelerde ve farklı illerde yaşayan katılımcıların dâhil olduğu daha büyük örneklem hacimlerinde çalışmalar yapılabilir. Çalışmanın kısıtlarını oluşturan zaman ve maliyet unsurlarından dolayı ve müşterilerin alışveriş öncesinde, esnasında ve sonrasında izlenmesi zor olacağından çalışmada çevrimiçi anket metodu kullanılmıştır. Ayrıca nitel araştırmalarla desteklenen çalışmalar yapılabilir.

Çalışmanın AVM yöneticilerine ve çalışanlarına müşterileri için olumlu deneyimler sunmaları açısından katkı sağlayacağı düşünülmektedir. Ayrıca çalışma alışveriş merkezinde müşterinin demografik özelliklerine göre farklılaşmasından yola çıkarak pazarlama stratejileri geliştirilmesine katkı sağlayabilir.

İlerleyen çalışmalarda, deneyimsel pazarlama kavramı ve stratejik deneyimsel pazarlama boyutları ele alınarak farklı hizmet işletmelerindeki müşterilerin yaşadığı deneyimlerin, müşteri bağlılı̆̆ına etkisi araştırılabilir. Deneyimsel pazarlama boyutları farklı AVM müşterileri ile karşılaştırmalı olarak da incelenebilir.

\section{REFERENCES / KAYNAKLAR}

Alemdar, Y. M. (2010). Deneyimsel pazarlamada alışveriş atmosferinin tüketici davranışları üzerindeki etkisi (Doktora tezi). Ege Üniversitesi, İzmir. 
Argan M. (2007). Eğlence pazarlaması. Ankara: Detay Yayıncılık.

Arslan, F. M. (2004). Mă̆azacılıkta atmosfer. İstanbul: Derin Yayınları.

Arussy L. (2007). The experience: How to wow your customers and create a passionate workplace. CRC Press, Erişim adresi: Taylor and Francis, https://www.taylorfrancis.com/books/9780429085987

Bahçecioğlu, A. (2014). Sanal deneyimsel pazarlamanın tüketici tutumuna etkisi (Yüksek lisans tezi). Ege Üniversitesi, İzmir.

Barutçugil, İ. (2009). Müşteri ilişkileri ve satış yönetimi. İstanbul: Kariyer Yayıncılık.

Başar, B. (2015). Kültür ve sanat faaliyetlerinde deneyimsel pazarlamanın müşteri sadakatine etkisi (Yüksek lisans tezi). Gazi Üniversitesi, Ankara.

Baştuğ, M. (2018). Deneyimsel pazarlama ile hizmet kalitesi arasındaki ilişki ve bir uygulama (Yüksek lisans tezi). Marmara Üniversitesi, İstanbul.

Bat1, U. (2017). Markethink ya da farkethink: Deneyimsel pazarlama ve duyusal markalama. İstanbul: Kitap Kulubü.

Berry, L. L. Carbone, L. P. \& Haeckel, S. H. (2002). Managing the total customer experience. Sloan Management Review, 43(3), 85-89.

Brakus, J., Schmitt, B. \& Zarantonello, L. (2009). Brand experience: What is it? How is it measured? Does it affect loyalty? Journal of Marketing, 73, 52-68.

Çalışkanman, B. (2015). Deneyimsel pazarlamanın tüketici satın alma kararlarına olan etkisi, starbucks ve kahve diyarı deneyimleri karşılaştırması (Yüksek lisans tezi). Gediz Üniversitesi, İzmir.

Çeltek, E. (2010). Deneyimsel pazarlama unsurlarının oteller in bakış açısı ile değerlendirilmesi: Türkiye'deki 4 ve 5 yıldızlı otel işletmelerinde bir uygulama (Doktora tezi). Anadolu Üniversitesi, Eskişehir.

Deligöz, K. (2014). Deneyimsel pazarlama uygulamalarının marka tercihi üzerindeki etkisini belirlemeye yönelik bir araştırma (Kahve dünyası ve starbucks örneği). (Yüksek lisans tezi). Atatürk Üniversitesi, Erzurum.

Demirdöven, K. (2018). Müşteri deneyimi ustası (Ercan Kalit’in çalışmalarından). İstanbul: A7 Kitap Yayıncılık.

Dirsehan, T. (2012). Müşteri deneyimi tasarımı ve yönetimi. İstanbul: Hiperlınk Yayınları.

Durmuş, B. vd. (2013). Sosyal bilimlerde Spss ’le veri analizi. İstanbul: Beta Basım Yayım Dağıtım.

Ercan, E. (2018). Deneyimsel pazarlamanın hedonik tüketim üzerindeki etkisi: Tekstil sektörü (Yüksek lisans tezi). Necmettin Erbakan Üniversitesi, Konya.

Gegez A. E. (2007). Pazarlama araştırmaları. Beta Basım Yayım Dağıtım İstanbul.

Genç, B. (2009). Deneyimsel pazarlamanın tüketici satın alma kararlarına etkisi (Yüksek lisans tezi). Ege Üniversitesi, İzmir.

Günay, G. N. (2008). Hizmet pazarlamasından deneyimsel pazarlamaya: Bir güzellik merkezinde uygulama. Nevşehir Üniversitesi İktisadi ve İdari Bilimler Fakültesi: 13. Ulusal Pazarlama Kongresi, 25-29 Ekim, 64-72.

Güney, D. (2015). Deneyimsel pazarlamanın müşteri sadakatine etkisi: muğla'daki butik otellere yönelik uygulama (Yüksek lisans tezi). Muğla Sıtkı Koçman Üniversitesi, Muğla.

Gürbüz S. \& Şahin F. (2015). Sosyal bilimlerde araştırma yöntemleri: Felsefe- yöntem-analiz. İstanbul: Seçkin Yayınc1lik. 
Güzel, F. Ö. \& Papatya, N. (2012). Duygusal arayışların pazarlamayla dansı: Deneyim pazarlaması kavramsal analiz. Işsletme Araştırmaları Dergisi, 4(4), 109-125.

İslamoğlu, A. Hamdi \& Alnıç̧ı, Ü. (2016). Sosyal bilimlerde araştırma yöntemleri. İstanbul: Beta Basım Yayım Dağıtım.

Kalaycı, Ş. (2014). Spss uygulamalı çok değişkenli istatistik teknikleri. Ankara: Asil Yayınları.

Kalyoncuoğlu, S. (2018). Deneyimsel pazarlama. Ankara: Gazi Kitabevi.

Karakaşoğlu, M. \& Arslan, F. M. (2016). Mağaza hizmet ortamının marka imajına ve satın alma niyetine etkisi: P\&B ve H\&M örneği. Marmara Üniversitesi Öneri Dergisi, 12(46), 223-243.

Kara, G. (2015). Marka deneyimi ve tekrara satın alma arasındaki ilişkide müşteri tatminin rolü (Yüksek lisans tezi). Eskişehir Osmangazi Üniversitesi, Eskişehir.

Kara, M. \& Çiçek, B (2015). Deneyimsel pazarlama ve satın alma karar sürecine etkisi. Gümüşhane Üniversitesi Sosyal Bilimler Enstitüsü Elektronik Dergisi, 6(1), 177-200.

Kazançoğlu vd. (2011). Deneyimsel pazarlama yaklaşımı ile özel alışveriş kulüplerine yönelik mobil uygulamalar (aplikasyonlar). 16. Ulusal Pazarlama Kongresi, 230-234.

Kır, S. (2014). Deneyimsel pazarlama bağlamında test sürüşleri (Yüksek lisans tezi). Selçuk Üniversitesi, Konya.

Konuk, G. (2014). Deneyimsel pazarlama. Ankara: Detay Yayıncılık.

Lindstrom, M. (2014). Buy.ology. İstanbul: Optimist Yayınlar1.

Lin, K vd. (2006). An examination of the relationship between experiential marketing strategy and guests leisure behavior in Taiwan hot-spring hotels (Thesis for the degree of doctor of sport management united states sports academy).

Lu1g1, D., Oana, S. \& Mihai, T. (2012). The importance of establishing customer experience. Studies in Business and Economics, 7(1), 56-61.

Meyer, C. \& Schwager, A. (2007). Understanding customer experience. Harvard Business Review, 117-26.

Milman, A. (2006). The role of theming in destination development Turk-Kazak international tourism conference. Akdeniz University Alanya Faculty of Business, 20-26 November.

Morgan, M. (2009). Student travel experiences: Memories and dreams. Journal of Hospitality Marketing and Management, 18(2), 216-236.

Odabaşı, Y. (2013). Pazarlama iletişimi. Eskişehir: Anadolu Üniversitesi Yayınları.

Oral S. \& Yetim Ç. A. (2014). Deneyimsel değer, tüketici tatmini ve tüketici sadakati arasındaki ilişkisinin belirlenmesine yönelik bir araştıma. Dokuz Eylül Üniversitesi Sosyal Bilimler Enstitüsü Dergisi, 16(3), 469-497.

Özgören, F. (2013). Deneyimsel markalama. Istanbul Journal of Social Sciences, Spring(3), 1-19.

Özkent, B. (2012). Emsalsiz müşteri deneyimleri yaratmak. Ankara: Elma Yayınevi.

Özmen, A. (2016). Şehir markalamasında duygusal yaklaşım: Deneyimsel pazarlama. Internatıonal Conference on Eurasian Economies, 298-303.

Papatya, N. (2006). Pazarlamada değişimin ötesi: Yaratıcı ve yenilikçi pazarlama dönüşümü. Pazarlama Dünyası Dergisi, 20(1), 73-77. 
Pine, J. \& Gilmore, J. (1998). Welcome to the experience economy. Harvard Business Review, 97-105, https://hbr.org/1998/07/welcome-to-the-experience-economy.

Pine, J. \& Gilmore, J. (2012). Deneyim ekonomisi (Güncellenmiş Tekrar Basım). İstanbul: Optimist Yayınları.

Prahalad, C.K. \& Ramaswamy, V. (2000). Coopting customer competenct. Harvard Business Review, 79-87, https://hbr.org/2000/01/co-opting-customer-competence.

Same, S. (2012). Understanding experience marketing: Conceptual insightsand differences from experiential marketing. Tallinn University of Technology. 7(4), 68-79.

Schmitt, B. H. (1999). Experimental marketing. Journal of Marketing Management, 15(1-3), 53-67.

Shaw, C. \& Ivens, J. (2002). Building great customer expertence. NewYork, NY: Palgrave Macmillan.

Torlak, Ö, Altunışık, R. \& Özdemir, Ş. (2006). Yeni müşteri. İstanbul: Hayat Yayıncılık.

Tsai, S. (2005). Integrated marketing as management of holistic consumer experience. Business Horizons, 48(5), $431-441$

Tsaur, S. vd. (2007). The visitors behavioral consequences of experiental marketing: An empiricial study on taipei zoo. Journal of Travel \&Tourlsm Marketıng, 21(1), 47-64.

Tunç, R. (2017). Deneyimsel pazarlama ve müşteri memnuniyeti üzerine etkisi (Yüksek lisans tezi). İstanbul Ticaret Üniversitesi, İstanbul.

Türk Dil Kurumu (TDK). Deneyim Tanımı. Erişim tarihi: 10.01.2018, www.tdk.gov.tr/

Varinli, İ. (2008). Pazarlamada yeni yaklaşımlar. Ankara: Detay Yayıncılık. 